Prepared in cooperation with the National Fish and Wildlife Foundation

\title{
Technical Review of Managed Underground Storage of Water Study of the Upper Catherine Creek Watershed, Union County, Northeastern Oregon
}

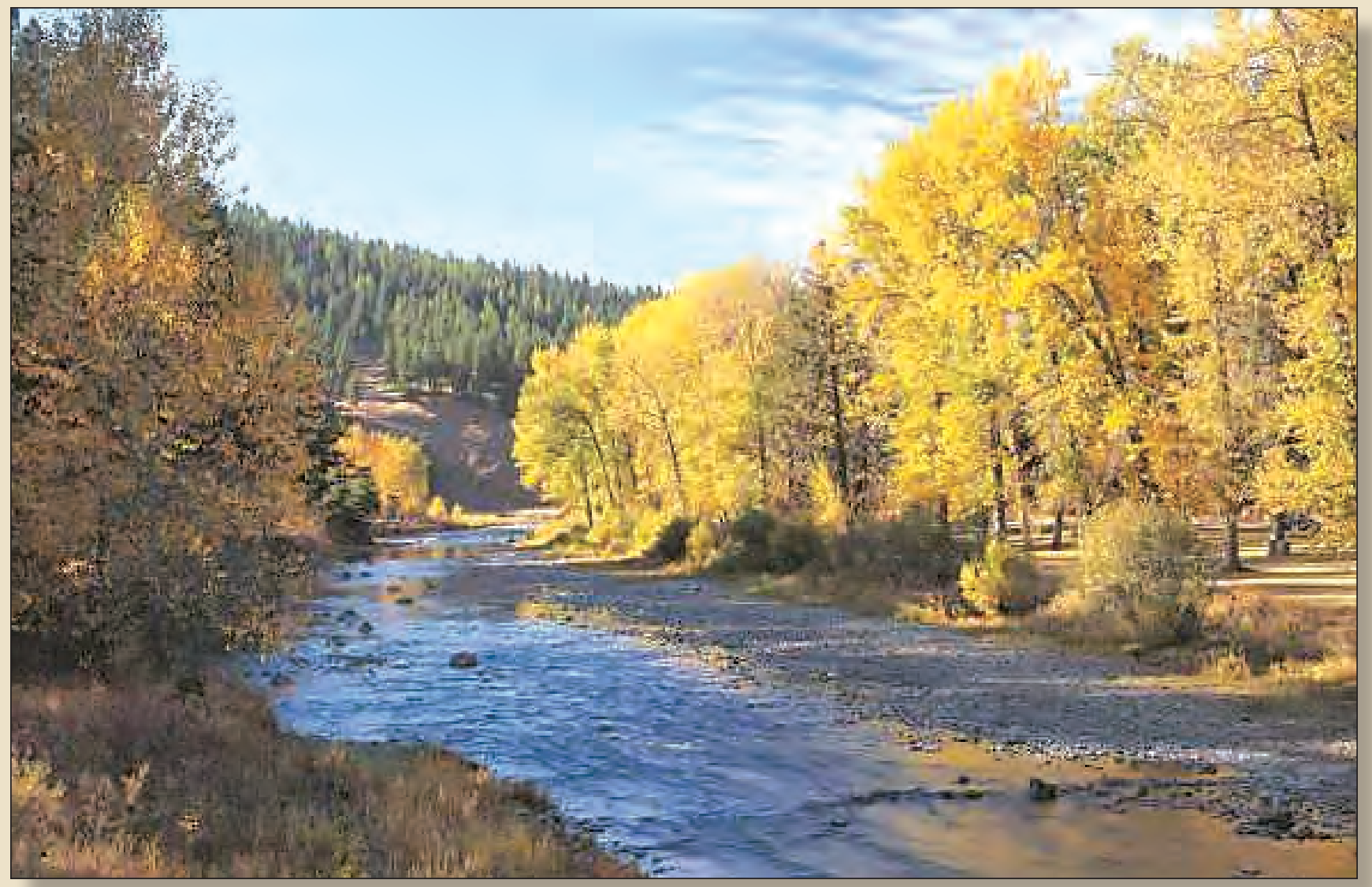

Open-File Report 2014-1164 
Cover: Photograph of Catherine Creek State Park, near Union, Oregon, showing

Catherine Creek in the foreground. (Photograph provided by Oregon State Parks. Used with permission.) 


\section{Technical Review of Managed Underground Storage of Water Study of the Upper Catherine Creek Watershed, Union County, Northeastern Oregon}

By Daniel T. Snyder

Prepared in cooperation with the National Fish and Wildlife Foundation

Open-File Report 2014-1164

U.S. Department of the Interior

U.S. Geological Survey 


\section{U.S. Department of the Interior \\ SALLY JEWELL, Secretary}

\section{U.S. Geological Survey \\ Suzette M. Kimball, Acting Director}

U.S. Geological Survey, Reston, Virginia: 2014

For more information on the USGS—-the Federal source for science about the Earth, its natural and living resources, natural hazards, and the environment-visit http://www.usgs.gov or call 1-888-ASK-USGS

For an overview of USGS information products, including maps, imagery, and publications, visit $h t t p: / / w w w . u s g s . g o v / p u b p r o d$

To order this and other USGS information products, visit $h$ ttp://store.usgs.gov

Suggested citation:

Snyder, D.T., 2014, Technical review of managed underground storage of water study of the upper Catherine Creek watershed, Union County, northeastern Oregon: U.S. Geological Survey Open-File Report 2014-1164, 38 p., http://dx.doi.org/10.3133/ofr20141164.

ISSN 2331-1258 (online)

Any use of trade, firm, or product names is for descriptive purposes only and does not imply endorsement by the U.S. Government.

Although this information product, for the most part, is in the public domain, it also may contain copyrighted materials as noted in the text. Permission to reproduce copyrighted items must be secured from the copyright owner. 


\section{Contents}

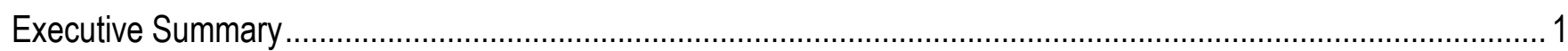

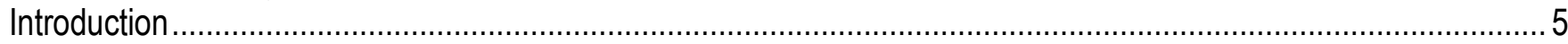

Purpose

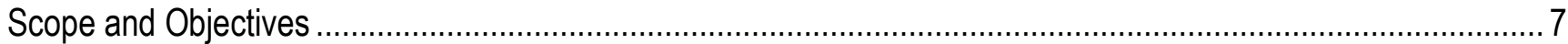

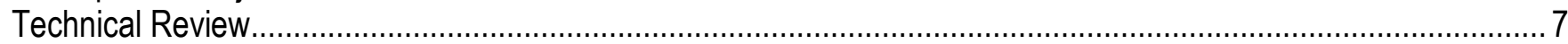

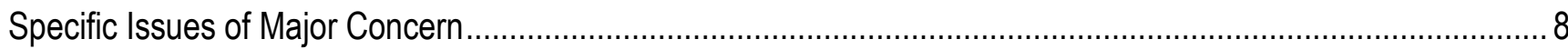

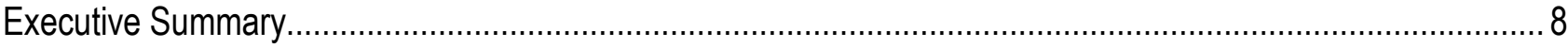

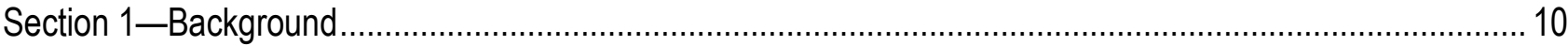

Section 2-Existing Stream Flows................................................................................................. 11

Section 3-Hydrogeologic Setting ................................................................................................ 11

Section 4-Water Quality Evaluation.................................................................................................. 14

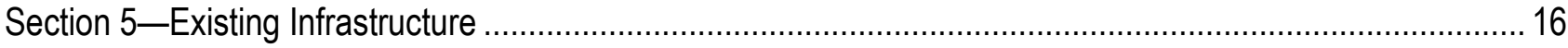

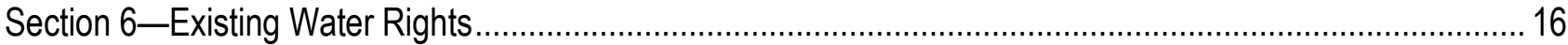

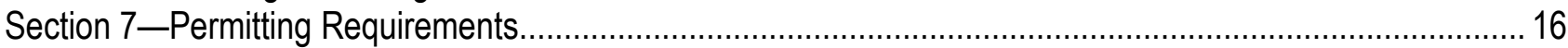

Section 8-Conservation and Efficiency ........................................................................................... 16

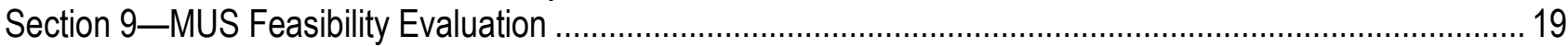

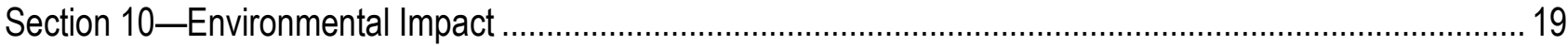

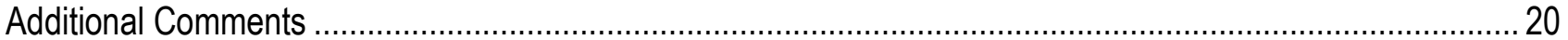

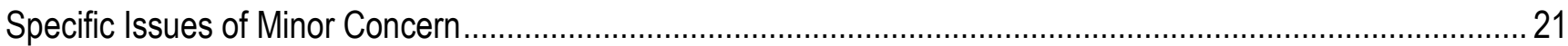

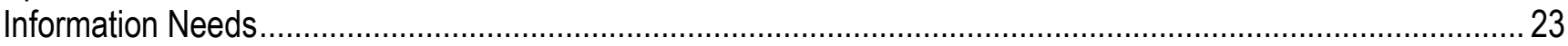

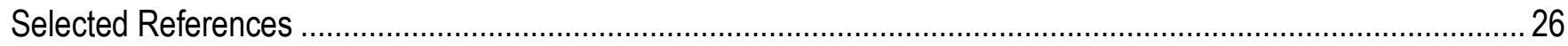

Appendix A. Typographical Errors and Issues of Minor Importance .................................................................... 29

Appendix B. Analysis of Water and Aquifer Storage Requirements................................................................. 31

\section{Figures}

Figure 1.Map showing location of the upper Catherine Creek watershed, Union County, northeastern Oregon....... 6 Figure 2.Graph showing water temperature and well depth for wells within about 8 miles of the Milk Creek sub-area (depths greater than 350 feet), upper Catherine Creek watershed, Union County, northeastern Oregon.

Figure 3.Graph showing daily mean streamflows, by year, and mean daily streamflow, at Oregon Water Resources Department stream gage 13320300 (based on daily mean discharge), Catherine Creek, Union County, northeastern Oregon, October 1997-September 2007

Figure 4.Graph showing percentiles of daily mean streamflow for individual dates, at Oregon Water Resources Department stream gage 13320300 (based on daily mean discharge), Catherine Creek, Union County, northeastern Oregon, October 1997-September 2007 


\section{Conversion Factors}

Exact conversion factors are noted in bold type. All other conversion factors have been rounded to four significant digits. To reduce errors resulting from rounded conversion factors, reverse conversions should multiply by the inverse of the conversion factors originally used. For example, to convert feet into meters multiply by 0.3048 . To convert meters into feet multiply by $1 / 0.3048$.

Inch/Pound to SI

\begin{tabular}{lcl}
\hline \multicolumn{1}{c}{ Multiply } & \multicolumn{1}{c}{ By } & \multicolumn{1}{c}{ To obtain } \\
\hline inch (in.) & Length & \\
inch (in.) & $\mathbf{2 . 5 4}$ & centimeter (cm) \\
foot (ft) & $\mathbf{2 5 . 4}$ & millimeter (mm) \\
mile (mi) & $\mathbf{0 . 3 0 4 8}$ & meter (m) \\
\hline & 1.609 & kilometer $(\mathrm{km})$ \\
\hline acre & Area & \\
acre & 4,047 & square meter $\left(\mathrm{m}^{2}\right)$ \\
square mile $\left(\mathrm{mi}^{2}\right)$ & 0.4047 & hectare $(\mathrm{ha})$ \\
square mile $\left(\mathrm{mi}^{2}\right)$ & 259.0 & hectare $(\mathrm{ha})$ \\
\hline & 2.590 & square kilometer $\left(\mathrm{km}^{2}\right)$ \\
\hline acre-foot $($ acre-ft) & Volume & \\
acre-foot $($ acre-ft) & 1,233 & cubic meter $\left(\mathrm{m}^{3}\right)$ \\
& 0.001233 & cubic hectometer $\left(\mathrm{hm}^{3}\right)$ \\
\hline cubic foot per second $\left(\mathrm{ft}^{3} / \mathrm{s}\right)$ & Flow rate & \\
\hline & 0.02832 & cubic meter per second $\left(\mathrm{m}^{3} / \mathrm{s}\right)$ \\
\hline pound per square inch $\left(\mathrm{lb} / \mathrm{in}^{2}\right)$ & Pressure & \\
\hline & 6.895 & kilopascal $(\mathrm{kPa})$ \\
\hline
\end{tabular}

$\underline{\text { SI to Inch/Pound }}$

\begin{tabular}{llll}
\hline & Multiply & By & To obtain \\
\hline & Length & \\
\hline meter $(\mathrm{m})$ & 3.281 & foot $(\mathrm{ft})$ &
\end{tabular}

Temperature in degrees Fahrenheit $\left({ }^{\circ} \mathrm{F}\right)$ may be converted to degrees Celsius $\left({ }^{\circ} \mathrm{C}\right)$ as follows:

${ }^{\circ} \mathrm{C}=\left({ }^{\circ} \mathrm{F}-32\right) / 1.8$

Horizontal coordinate information is referenced to the North American Datum of 1983 (NAD 83). Conversion between NAD 83 and the commonly used North American Datum of 1927 (NAD 27) varies spatially, and the difference in horizontal positions can be greater than 300 feet within the study area. For assistance with conversions, the reader is directed to either the National Geodetic Survey Web site for NADCON at $h t t p: / / w w w . n g s . n o a a . g o v / T O O L S / N a d c o n / N a d c o n . h t m / o r$ the U.S. Army Corps of Engineers Web site for Corpscon at http://www.agc.army.mil/Missions/Corpscon.aspx. 


\title{
Technical Review of Managed Underground Storage of Water Study of the Upper Catherine Creek Watershed, Union County, Northeastern Oregon
}

\author{
By Daniel T. Snyder
}

\section{Executive Summary}

Because of water diversions during summer, flow in Catherine Creek, a tributary to the Grande Ronde River in northeastern Oregon, is insufficient to sustain several aquatic species for which the stream is listed as critical habitat. A feasibility study for managed underground storage (MUS) in the upper Catherine Creek watershed in Union County, Oregon, was undertaken by Anderson Perry and Associates, Inc., to address the issue of low flows in summer. The results of the study were released as a report titled "Upper Catherine Creek Storage Feasibility Study for Grande Ronde Model Watershed," which evaluated the possibility of diverting Catherine Creek streamflow during winter (when stream discharge is high), storing the water by infiltration or injection into an aquifer adjacent to the stream, and discharging the water back to the stream in summer to augment low flows. The method of MUS would be accomplished using either (1) aquifer storage and recovery (ASR) that allows for the injection of water that meets drinking-water-quality standards into an aquifer for later recovery and use, or (2) artificial recharge (AR) that involves the intentional addition of water diverted from another source to a groundwater reservoir.

Concerns by resource managers that the actions taken to improve water availability for upper Catherine Creek be effective, cost-efficient, long-term, and based on sound analysis led the National Fish and Wildlife Foundation to request that the U.S. Geological Survey conduct an independent review and evaluation of the feasibility study. This report contains the results of that review.

The primary objectives of the Anderson Perry and Associates study reviewed here included (1) identifying potentially fatal flaws with the concept of using AR and (or) ASR to augment the streamflow of Catherine Creek, (2) identifying potentially favorable locations for augmenting streamflow, (3) developing and evaluating alternatives for implementing AR and (or) ASR, and (4) identifying next steps and estimated costs for implementation. The Anderson Perry study was not intended as a comprehensive evaluation of feasibility, but, rather, an effort to develop a concept and preliminary evaluation of feasibility. Additionally, the feasibility study was limited to using existing data from which additional data needs were to be identified. The feasibility study mostly accomplished the goals of identifying potential fatal flaws and developing a project implementation plan. However, a more practical discussion of conclusions regarding the feasibility, likelihood for success, achievement of goals, and overall project costs could have received greater emphasis and would be of value to decision makers. With regard to objective (2), the subject report analyzed information from several possible sites examined for an MUS system. Sufficient cause is provided in the subject report to identify the basalt aquifer in the Milk Creek sub-area as having the greatest potential for MUS. Therefore, this review is primarily focused on the Milk Creek sub-area and the basalt aquifer. 
Most of the subject report is clearly written, data are sufficient, analyses are correct, and the interpretations and conclusions are reasonable. However, this review identifies a number of technical issues and concerns. The issues of greatest concern identified in this review include the following:

- Available hydrogeologic data are lacking in the area selected as the primary target for an MUS system to determine the suitability of the area for MUS. The hydrogeologic analysis of the Milk Creek sub-area used only two wells, which are relatively close to each other. From a review of the Oregon Water Resources Department (OWRD) GRID database of well records, these two wells seem to be the only wells in this area. The feasibility study was limited to use of existing data and appropriately indicates the importance of the need for additional data collection. However, reliance on such a small number of wells for the identification of an area for an MUS system is not ideal. The geometry of the geologic units in this area is complex, as is the lithology, making it challenging to readily determine the geologic units (and their extent and thickness) present in the target area. The lack of data also makes it difficult to evaluate the hydraulic properties of the target aquifer (Grande Ronde aquifer) in this area and to determine the amount of variation that may be present. The extensive number of geologic structures, especially faults, mapped in this area adds to the complexity of evaluating the hydrogeology. The small number of drillers' well logs for this area limit the availability of lithologic descriptions, water levels, water temperatures, and other observations that otherwise would be helpful to determine the influence of these geologic structures on the hydrogeology in the planned target area and what effect they may have on the performance of the MUS system. In other areas of the Columbia Plateau, such structures have been shown to compartmentalize and isolate parts of the aquifer. Compartmentalization could limit significantly the ability of the MUS system to store and recover water.

- The volumetric analysis in the subject report of the quantity of water to be stored in the aquifer does not consider the volume of aquifer necessary to accommodate the volume of water. This relates directly to the suitability of the Columbia River Basalt Group as a potential aquifer for use in an MUS system in the Milk Creek sub-area. A simplified analysis was done as part of this review using a range of expected hydraulic properties. The presence of flowing artesian wells in the Milk Creek sub-area indicates that the Grande Ronde aquifer is confined in this area. Large head changes across extensive areas are required to store or yield substantial quantities of water from confined aquifers as compared to unconfined aquifers. Using the expected water volumes for the MUS system and the range of values for the hydraulic properties of the Grande Ronde aquifer, the change in head required to accommodate the storage of recharge water can be estimated for various possible aquifer surface areas. For a flow augmentation rate of $1 \mathrm{ft}^{3} / \mathrm{s}$ that requires a recharge water volume of 287 acre- $\mathrm{ft}$, the necessary change in head ranges from about $3.7 \mathrm{ft}$ for an aquifer with a $20-\mathrm{mi}^{2}$ areal extent and having the maximum storage properties to a physically unreasonable $640,000 \mathrm{ft}$ for a confined aquifer with only a $0.5 \mathrm{mi}^{2}$ areal extent and having the minimum storage properties. For a flow augmentation rate of $10 \mathrm{ft}^{3} / \mathrm{s}$ that requires a recharge water volume of 2,871 acre- $\mathrm{ft}$, the necessary change in head ranges from about $37 \mathrm{ft}$ for an aquifer with a $20-\mathrm{mi}^{2}$ areal extent and having the maximum storage properties to a physically unreasonable $6,400,000 \mathrm{ft}$ for a confined aquifer with only a $0.5 \mathrm{mi}^{2}$ areal extent and having the minimum storage properties. For comparison, the low-lying part of the Milk Creek sub-area is less than $1 \mathrm{mi}^{2}$. The extreme values of head (greater than hundreds or thousands of feet) that 
might be needed to store the recharge water volumes for the MUS system in a relatively small aquifer surface area probably are not feasible from an engineering perspective. Conversely, the large aquifer surface area (greater than tens of square miles) that might be needed to store the recharge water volumes for the MUS system with a relatively small change in head probably are not feasible from a hydrogeologic perspective because of geologic features that may occur at a smaller scale such as pinchouts of the aquifer, changes in lithology, or the presence of faults. Using 100 pounds per square inch $\left(1 \mathrm{~b} / \mathrm{in}^{2}\right)$ as the practical upper limit for injecting water under pressure and a value of $2.31 \mathrm{ft}$ of head per $\mathrm{lb} / \mathrm{in}^{2}$ results in a practical upper limit of $231 \mathrm{ft}$ of head for injecting water under pressure. Using the minimum, median, and maximum values of the storage coefficient for the Grande Ronde aquifer, the aquifer surface area required would be 1,$400 ; 3.7$; and $0.32 \mathrm{mi}^{2}$, respectively, for a flow augmentation rate of $1 \mathrm{ft}^{3} / \mathrm{s}$ that requires a recharge water volume of 287 acre-ft. Aquifer surface areas of 14,$000 ; 37$; and $3.2 \mathrm{mi}^{2}$, respectively, would be required for a flow augmentation rate of $10 \mathrm{ft}^{3} / \mathrm{s}$ that requires a recharge water volume of 2,871 acre-ft.

- The flowing artesian conditions in the basalt aquifer in the Milk Creek sub-area may limit the available storage and may require wellhead equipment designed for water injection under pressure. The feasibility and cost of storage in a confined aquifer are relevant to the feasibility study.

- The subject report notes that the results of a 24-hour aquifer test in the Milk Creek sub-area showed indications of a negative boundary (a feature within the aquifer that may constrain the transmission of groundwater such as faults or changes in lithology) within the target basalt aquifer. Review of the source aquifer-test report indicates that a second negative boundary also was identified. The presence of negative boundaries within the aquifer may have a substantial effect on the performance of an MUS system. As noted in the feasibility study, additional aquifer testing is needed to better understand the hydrologic conditions of the aquifer.

- The Executive Summary of the subject report does not address the possible cost of acquiring some or all of the senior surface-water rights close enough to the confluence of Catherine Creek and the Grande Ronde River to attain the desired 1-10 $\mathrm{ft}^{3} / \mathrm{s}$ of streamflow augmentation. This option might be an important alternative to consider and compare to the cost to design, build, operate, and maintain an MUS system, along with the other alternative measures discussed in the subject report, such as water conservation and improved irrigation efficiency.

- There is relatively little discussion of the possible cost of enlisting interested water-rights holders in the OWRD Allocation of Conserved Water Program under which the State retains at least 25 percent of water conserved, with possible allocation to the State as great as 75 percent. The reviewed report does not indicate the additional advantage of this program that a new waterright certificate is issued for the State instream water right with a priority date either the same as the original right, or one minute junior. If senior water-rights holders (especially those with points of diversion and place of use located near to the confluence of Catherine Creek and the Grande Ronde River) are targeted for participation, then the instream water rights acquired by the State could have a priority date that is the same as the original priority date. This could help ensure that the conserved water quantity would be protected from diversion upstream of waterrights holders with lessor priority dates, and could be a cost-effective solution to meeting the inflow stream goals of the subject report. 
- In the Project Implementation Plan, the possibility of placing a higher priority on confirming whether OWRD will support the approach of defining the place of use for water withdrawn from the proposed MUS system as the mouth of Catherine Creek, and using a secondary permit to "shuttle" water from the Milk Creek sub-area to the place of use should be considered. The purpose of such a designation is to protect streamflows enhanced by implementation of the MUS alternative from appropriation for use by senior water-rights holders and other downstream users. This evaluation likely would cost little compared to the hydrogeologic evaluation, and if this is not feasible, then the benefits of the project may be in doubt. Informal discussions with OWRD for this review indicated that it might be possible to use the method proposed to ensure that water recovered from the MUS system is available in Catherine Creek all the way to the confluence of the Grande Ronde River. Additional discussion is needed regarding alternatives to protecting water discharged by the MUS system from diversion by other water users if the water cannot be "shuttled".

- As discussed in the feasibility study, the water-quality data are sparsely distributed and incomplete, and the sample locations are not located specifically in the area(s) where MUS may be implemented. The lack of data hinders the ability to determine the suitability of the area for MUS. However, the recommendations to fill existing data gaps are appropriate and generally cover the areas where additional information is needed either to meet regulatory considerations or to better estimate performance of the MUS system with regard to geochemical compatibility of the surface water and groundwater within the aquifer matrix.

- Water temperature is not mentioned in the evaluation of water-quality data. The subject report and several of the drillers' logs for the basalt wells presented in the subject report indicate a relatively wide range of groundwater temperatures $\left(50-72^{\circ} \mathrm{F}\right)$. As part of this review, an examination of drillers' logs from OWRD for wells more than $350 \mathrm{ft}$ deep within $8 \mathrm{mi}$ of the Milk Creek sub-area identified wells with temperatures as great as $81^{\circ} \mathrm{F}$. This could be a significant factor if the temperature of discharge water from the MUS system is of regulatory concern with regard to Total Maximum Daily Load (TMDL) of the Upper Grande Ronde River subbasin, or of concern with regard to environmental effects downstream. The temperature of the discharge water from the MUS system could result in either beneficial or detrimental effects on Catherine Creek. Discharge temperatures less than the temperature of the stream may create cold-water refugia for aquatic species and may reduce the potential for TMDL temperature violations downstream. Discharge temperatures greater than the temperature of the stream may negatively affect aquatic species and may violate the Upper Grande Ronde River subbasin TMDL for temperature.

- There is not sufficient information to determine the potential for local or distant effects on the environment or on other water users that may result from the operation of an MUS system in the Milk Creek sub-area. The extent of possible hydrologic effects is dependent on a number of factors including whether the aquifer used for MUS is confined or unconfined (appendix B). Generally, for an unconfined aquifer, it is unlikely that effects of the storage and withdrawal of water in the Milk Creek sub-area would manifest in the groundwater system in the area of the city of Union, $8 \mathrm{mi}$ to the north, and would affect groundwater levels, groundwater exchange with streams, wetlands, or springs and interfere with groundwater withdrawals by agricultural and other water users. Because of the distance, complexity of the geology, and presence of geologic structures, if effects were to occur, long periods of time may be required for such effects to be readily perceived. If the aquifer is compartmentalized, owing to aquifer geometry or structural features such as faults, then this could limit the extent of detrimental effects from 
MUS. However, for a confined aquifer, the aquifer storage requirements needed to accommodate the volume of water proposed for the MUS system may necessitate large head increases across an extensive aquifer. Therefore, the affected aquifer could extend substantial distances, which may then expand the potential area for environmental effects. Therefore, this issue remains unresolved pending further definition of the hydrologic and water-quality conditions present in the Milk Creek sub-area and the necessary aquifer storage requirements needed to meet the goals of the MUS system.

- With regard to the potential for local environmental effects or effects on other water users for the primary selection of the Milk Creek sub-area as the location for an MUS system, water use is limited in the immediate area. However, local hydrologic features in the immediate area such as groundwater exchange with Catherine Creek, nearby wetlands, and springs may be subject to changes owing to the storage or withdrawal of water from the aquifer. If the aquifer is confined, aquifer pressure may need to be increased to accommodate the storage of the target rechargewater volumes for MUS. The increase in pressure would raise the head in the aquifer and might have several effects such as (1) causing previously non-flowing wells to begin to flow at land surface; (2) increasing the upward vertical flow of water into the overlying alluvial aquifer, thereby raising groundwater levels; (3) increasing discharge to wetlands; or (4) increasing baseflow discharge to Catherine Creek at unintended times. If the aquifer is compartmentalized, the environmental effects could be amplified because they would be distributed across a smaller area. Environmental effects, particularly with regard to the quantity and temperature of water, could be either beneficial or detrimental. This issue remains unresolved pending further definition of the hydrologic and water-quality conditions present in the Milk Creek sub-area and the required aquifer volumes needed to meet the goals of MUS. If further work on feasibility is done, consideration should be given to installing continuous water-level recorders in the alluvial aquifer, basalt aquifer, and Catherine Creek to determine the possible interconnections between the alluvial aquifer, the basalt aquifer, and Catherine Creek that, if present, could then be used to determine the possible magnitude of water-level changes and local environmental effects.

\section{Introduction}

As a result of water diversions during summer, flow in Catherine Creek, a tributary to the Grande Ronde River in northeastern Oregon (fig. 1), (which is listed as critical habitat for Chinook salmon [Oncorhynchus tshawytscha], steelhead [Oncorhynchus mykiss], and bull trout [Salvelinus confluentus]) is insufficient to sustain aquatic species. In 2009, the Grande Ronde Model Watershed contracted with Anderson Perry and Associates, Inc., to conduct a feasibility study for managed underground storage (MUS) in the upper Catherine Creek watershed in Union County, Oregon, to address the issue of low flows in summer. In 2010, Anderson Perry released their report titled "Upper Catherine Creek Storage Feasibility Study" (Anderson Perry and Associates, Inc., 2010), which evaluates the feasibility of diverting Catherine Creek streamflow during winter (when stream discharge is high), storing the water by infiltration or injection into an aquifer adjacent to the stream, and discharging the water in summer to augment low flows. The method of MUS would be accomplished using either aquifer storage and recovery (ASR) or artificial recharge (AR). ASR allows for the injection of water that meets drinking water quality standards into an aquifer for later recovery and use (Oregon Water Resources Department, 2013a). AR involves the intentional addition of water diverted from another source to a groundwater reservoir (Oregon Water Resources Department, 2013b). 


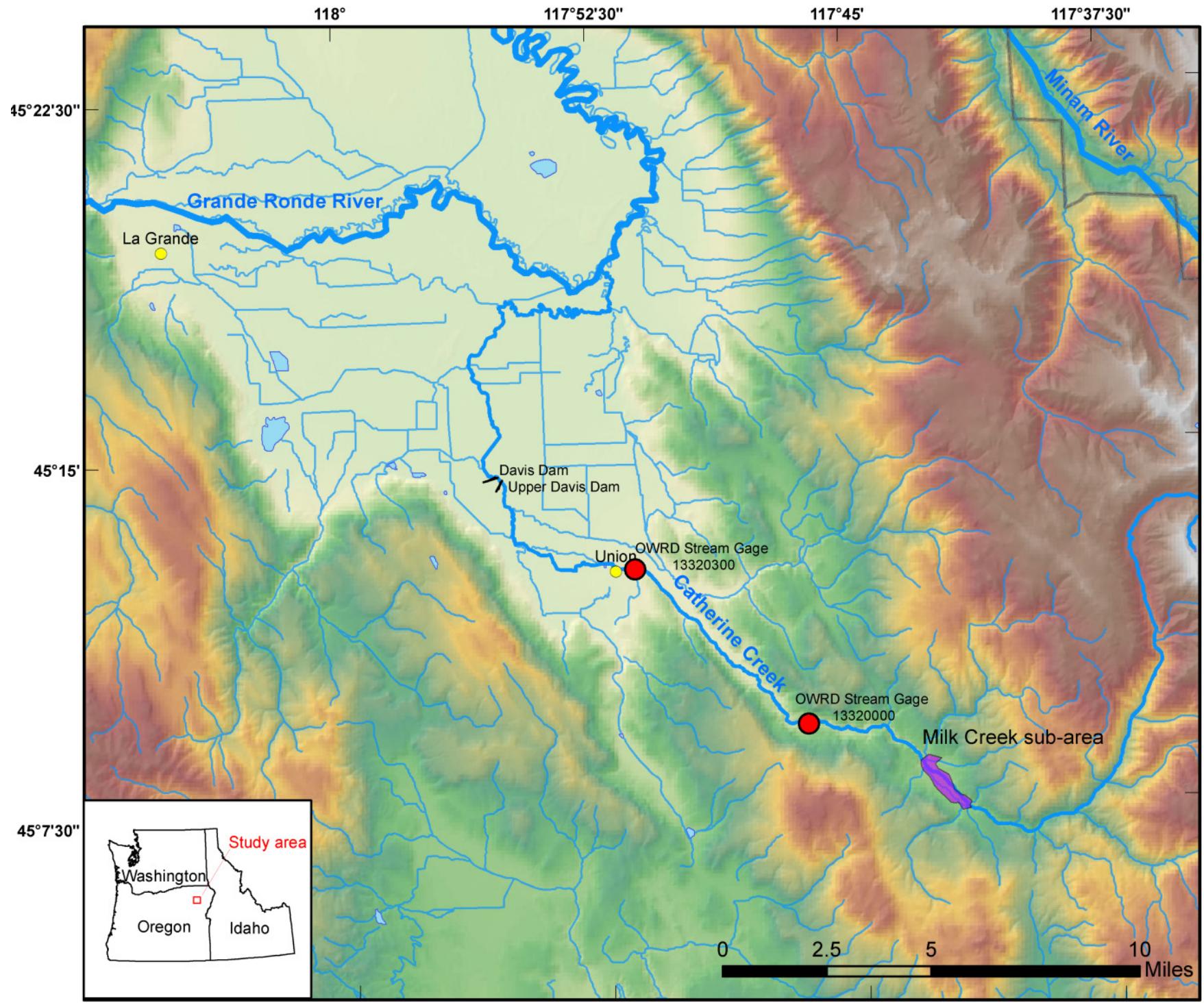

Figure 1. Map showing location of the upper Catherine Creek watershed, Union County, northeastern Oregon.

Water- and land-resource managers are concerned that the actions taken to resolve wateravailability issues for upper Catherine Creek be effective, cost-efficient, long-term, and based on sound analysis. To address these concerns, the National Fish and Wildlife Foundation requested in 2012 that the U.S. Geological Survey (USGS) conduct an independent review and evaluation of the feasibility study to assist resource managers in gaining a better understanding of the feasibility study's technical aspects and sufficiency of the analysis. 


\section{Purpose}

This report presents the results of the USGS review of the Anderson Perry and Associates, Inc. (2010) feasibility study. The review highlights and, where necessary, expands on issues presented in the feasibility study. The review also identifies key omissions in the feasibility study. The USGS conducted the review primarily using information contained in the subject report; a small amount of additional information was used that was obtained from readily available sources as cited and referenced in the review. The USGS collected no additional field measurements or other new data.

\section{Scope and Objectives}

The objectives of this review include the following:

- Identify and evaluate the assumptions that are critical to the feasibility of MUS in upper Catherine Creek.

- Assess the sufficiency of the data and analyses that were used to determine local and distant aquifer effects.

- Assess the sufficiency of the data and analyses that were used to evaluate surface-water and groundwater quality issues.

- Identify the most significant data gaps and how they might be addressed.

- Identify issues not addressed in the feasibility study and any additional analyses that may be needed to resolve issues using existing data or with additional data collection.

The subject report analyzes information from several possible sites examined for an MUS system. Sufficient cause is provided in the subject report to identify the basalt aquifer in the Milk Creek sub-area as having the greatest potential for MUS. Therefore, this review primarily is focused on the Milk Creek sub-area and the basalt aquifer.

Not all data, analyses, or conclusions presented in the subject report could be verified. Additionally, in the interest of conciseness, this review does not comment on all aspects, assumptions, or conclusions. This should not be construed as validation of these components of the report by this review. Rather, the focus of this review is on the major elements that are of such significance that they may influence the overall conclusions and for which the assumptions, data, analyses, or interpretations were either missing or deemed incorrect, insufficient, or unsupported by available information.

\section{Technical Review}

The technical review was divided into three sections: The first section addresses our specific issues of major concern, the second section discusses specific issues of minor concern, and the third section identifies information needs that may be present. Additionally, appendix A contains a list of typographical errors and issues of minor importance. References to specific sections or parts of the subject report are identified in italics. This document identifies technical issues and concerns as directed in the objectives of this review. However, it should be noted that most of the feasibility study is clearly written, data gaps are identified, available data are used appropriately, analyses are correct, and the interpretations and conclusions are reasonable. 


\section{Specific Issues of Major Concern}

This section contains comments on issues that were considered of major concern with regard to the data, analyses, interpretations, or conclusions in the subject report. It is organized by each section of the report, and each comment is preceded by its location in the report and its context.

\section{Executive Summary}

The Executive Summary of the report is perhaps the most important section in the document because many readers may only take the time to review this information. For this reason, it is vital that this section accurately and completely reflect the findings presented in the body of the report. Following are suggestions to improve the Executive Summary that would help readers gain a fuller understanding of the subject report and its major findings.

Hydrogeologic Setting, p. ES-2, fourth paragraph.-There is no mention in the study report Executive Summary of the general lack of available hydrogeologic data in the area of the preferred alternative site, the Milk Creek sub-area, to determine the suitability of the sub-area for MUS. Additional information is needed to delineate the aquifer geometry, extent, and hydraulic properties, as well as the possible presence of geologic structures.

Several areas of discussion should have been included in the Executive Summary with regard to the hydrogeologic conditions in the Milk Creek sub-area based on currently available data. These conditions include flowing artesian conditions in the basalt aquifer, and how flowing artesian conditions may affect storage volumes, infrastructure, and MUS costs; aquifer requirements such as the head needed under confined aquifer conditions to accommodate the water storage goals of the MUS system; and negative boundaries (features within the aquifer that may constrain the transmission of groundwater such as faults or changes in lithology) observed in the test well that may have implications for water storage.

Existing Water Rights, p. ES-4, second paragraph.--In the summary of Section 6-Existing Water Rights, the potential for the purchase of a senior water right as a cost-effective means to ensure 1 $\mathrm{ft}^{3} / \mathrm{s}$ of flow in Catherine Creek is presented; however, it is not included in the Executive Summary of the subject report. This is a major conclusion and a necessary part of the Executive Summary.

Conservation and Efficiency, p. ES-5, second paragraph.- The statement made in this paragraph of the subject report is not entirely accurate:

It is estimated that about $80 \mathrm{cfs}$ [cubic feet per second] could be conserved through efficiency improvements for $\$ 15$ to $\$ 30$ million. This conserved amount is much less than the 130 cfs of overappropriated water downstream of the gauging station alone. Furthermore, there currently is no mechanism in place to protect flows augmented by conservation and efficiency. Efficiency and conservation have the potential to provide increased irrigation to a larger number of water users for a longer period of the irrigation season; however, they do not have the potential to provide stream flow enhancement for fish passage and stream health. 
The Oregon Water Resources Department (OWRD) Allocation of Conserved Water Program is described in Section 8, p. 8-3, paragraph 4 as:

Currently, the State will retain at least 25 percent of water saved due to incentives for water use efficiency under Statutes and Oregon Administrative Rules associated with Oregon's Conserved Water Program (ORS [Oregon Revised Statutes] 537.470(3)). If more than 25 percent of the funds used to finance the conservation measures comes from federal or state public sources and is not subject to repayment, the percentage of water allocated to the State is equal to the percentage of public funds used to finance the conservation measures (ORS 537.470(3)). The water right holder may always choose to retain up to 25 percent of the conserved water (ORS 537.470(3)). Enhanced in-stream flow is dependent on a water right holder's willingness to participate in the Conserved Water Program, the source of funding for conservation and efficiency measures, and their willingness to transfer up to 75 percent of the water saved to the State.

However, it did not mention the following condition that can be applied to the conserved water: "A new water right certificate is issued with the original priority date reflecting the reduced quantity of water being used with the improved technology. Other certificates are issued for the applicant's portion of the conserved water and for the state's instream water right. The priority dates for these certificates are either the same as the original right, or one minute junior (ORS 537.485 and OAR [Oregon Administrative Rules] 690-18)." (Oregon Secretary of State, 2014; Oregon State Legislature, 2014a; Oregon Water Resources Department, 2014a)

If senior water-rights holders with points of diversion and place of use located near the confluence of Catherine Creek and the Grande Ronde River are targeted for participation, and possibly provided with incentives, then the instream water rights acquired by the State could have a priority date that is the same as the original priority date. This could help ensure that the conserved quantity of water would be protected from diversion upstream of water-rights holders with lessor priority dates. It would no longer be necessary to obtain an additional $130 \mathrm{ft}^{3} / \mathrm{s}$ of instream flow to meet the needs of water-rights holders upstream. Only $1-10 \mathrm{ft}^{3} / \mathrm{s}$ of instream water rights would need to be acquired. This could be a costeffective solution to meeting the inflow stream goals of the subject report.

The statement_ - "Efficiency and conservation have the potential to provide increased irrigation to a larger number of water users for a longer period of the irrigation season; however, they do not have the potential to provide stream flow enhancement for fish passage and stream health" - is not accurate with regard to the provisions of ORS 537.470(3).

A cost-benefit analysis using cost per acre-foot of water or per cubic foot per second of water for a specified duration would help decision makers to better facilitate comparison of options to increase streamflow in Catherine Creek.

MUS Feasibility Evaluation, p. ES-6, second paragraph.- The following task should be included in Task 1-Pre-Feasibility Evaluation:

- Develop preliminary estimate of available storage within aquifer to determine if it is sufficient for intended purpose.

MUS Feasibility Evaluation, p. ES-6, third paragraph.- The following tasks should be included in Task 2-Hydrogeologic Feasibility Evaluation:

- Install continuous stream stage-discharge and temperature gages near Milk Creek sub-area.

- Begin continuous or monthly monitoring of groundwater levels and temperature of the planned shallow exploratory wells in Milk Creek sub-area. 
- Begin continuous monitoring of groundwater levels and temperature of both Bonneville Power Administration (BPA) test wells in the Milk Creek sub-area.

- Collect and analyze water quality of BPA test wells.

- Conduct a geochemical compatibility analysis of water in Catherine Creek and aquifer.

- Conduct a geochemical analysis of how introduced water may be modified by the host rock.

- Conduct a baseline FLIR (forward-looking infrared imaging) assessment of wetlands, springs, and seepage faces in the area to see where they are occurring and to approximate flows before start of operations for comparison following initiation of MUS. Ideally, this should be done at season or time of day to maximize temperature differential between groundwater and land-surface or surface water.

- Maintain exploratory wells as possible long-term monitoring wells.

MUS Feasibility Evaluation, p. ES-7, sixth paragraph.-Task 4-Design and Construction calls for a single Columbia River Basalt Group (CRBG) monitoring well. Additional monitoring wells may provide helpful information with regard to the performance of the aquifer and give a better spatial representation of how groundwater levels are responding. Some of these wells may need to be deeper than the current existing wells. A multi-level piezometer nest to obtain data on vertical gradients within the basalt aquifer and for comparison with the alluvial aquifer would be useful. A nested piezometer near Catherine Creek also may help in examining the relation between the shallow aquifer and stream stage. Ideally, this information should be acquired prior to operation of the MUS system to serve as baseline data and during the recharge and recovery phases for evaluation of how the vertical gradients change with operation of the MUS system. The installation of any additional wells should include analysis of the drill cuttings for identification of the geologic unit and evaluation of the hydraulic properties of the aquifers and confining layers.

\section{Section 1-Background}

Document Organization, p. 1-3, third paragraph.-The task under 3. Aquifer Hydrogeology to "estimate potential injection and recovery rates and storage volumes" accomplished the estimate of storage volume of water, but did not include the estimation of aquifer volume required for storage of the water volume under unconfined conditions or the areal extent and head change required under confined conditions. These estimates are essential to determine the practical capability of the aquifer to accommodate the quantity of water intended to be stored (see review Section 3-Hydrogeologic Setting-Hydrogeology, p. 3-7, first paragraph).

Document Organization, p. 1-4, fifth paragraph.-Under Conservation and Efficiency is the following task: "provide data for a comparative analysis of the cost/benefit of ASR or AR to conservation and efficiency improvements." The completed task does not include a direct comparison of the cost per cubic foot per second of water or cost per acre-foot of water between (1) conservation and efficiency, (2) ASR or AR, and (3) acquisition of water rights. A direct comparison would be helpful to decision makers. A meaningful comparison is not possible without accurate information on the range of values for the acquisition of land or water rights. 


\section{Section 2-Existing Stream Flows}

Ecological Flows, p. 2-2, third paragraph; Ecological Flows, p. 2-6, third paragraph.Citations should have been provided to support the statements "A minimum of $1 \mathrm{cfs}$ is considered in this Study to provide adequate stream flow enhancement for the purpose of fish migration and stream health" and "A maximum of 10 cfs would meet the Oregon Department of Fish and Wildlife desired fish flow for fish passage." The target stream flows are critical to determining the feasibility of an MUS system to obtain the flows that accomplish the project goals and the costs needed to do so. Therefore, proper documentation of the target flows is needed.

\section{Section 3-Hydrogeologic Setting}

\section{Hydrogeology, p. 3-5, second paragraph, and p. 3-6 table titled "Aquifer characteristics} and Well Performance-Alluvial Aquifer".- It would be helpful if this table showed the number of wells used for evaluation of each sub-area. It seems that only five well logs are presented in appendix $C$ of the study report that, according to the text, were used to determine aquifer characteristics. For the table, three wells are near the Union sub-area, two wells are near the Milk Creek sub-area, and no wells are near Badger Flat sub-area. The information for the Badger Flat sub-area apparently comes from the driller's log for well UNIO 51670 shown on figure 3-4 but is not included in appendix $C$ of the study. Depending on the actual number of wells used to determine the table of alluvial aquifer characteristics, it may need to be emphasized that a very small number of wells across a large area were used to determine the aquifer characteristics because of the lack of available well data. This may lead to great uncertainty regarding the presence or absence of the aquifer and the values of the aquifer characteristics. The lack of knowledge of the geometry, hydraulic characteristics, existence of multiple aquifers, and the possible presence of structural features (all of which could affect the performance of the MUS system) should be of concern.

Hydrogeology, p. 3-7, first paragraph.-One of the considerations cited in the suitability of the CRBG as a potential aquifer for use in MUS is the "Available Headroom"; however, this issue was not discussed much. The presence of flowing artesian wells in the Milk Creek sub-area indicates that the Grande Ronde aquifer is confined in this area. The volume of water stored to or released from a confined aquifer is a function of the surface area of the aquifer, the change in head, and the storage coefficient. The storage coefficient, in turn, is a function of the compressibility of the aquifer skeleton, the compressibility of water, the porosity, and the thickness of the aquifer. Expected values of the storage coefficient for the Grande Ronde aquifer range from a minimum of 0.0000014 to a maximum of 0.006 dimensionless units (Davies-Smith and others, 1988, p. 69; Hansen and others, 1994, p. 32-33; Packard and others, 1996, p. 57; Kahle and others, 2011, p. 25-26).

A volumetric analysis of the quantity of water to be stored in the aquifer and the aquifer storage requirements necessary to accommodate the volume of water would be extremely useful. As an example, appendix B, prepared as part of this review, contains a simplified analysis of the volumes of water and aquifer storage requirements that might be required for the MUS project as described in the study. Using the expected water volumes (appendix B, table B1) and the range of values for storage coefficient for the Grande Ronde aquifer, the change in head required to accommodate the storage of recharge water can be estimated for various possible aquifer surface areas (appendix B, figs. B3 and B4). For a flow augmentation rate of $1 \mathrm{ft}^{3} / \mathrm{s}$ that requires a recharge water volume of 287 acre- $\mathrm{ft}$, the 
necessary change in head ranges from about $3.7 \mathrm{ft}$ for an aquifer with a $20 \mathrm{mi}^{2}$ areal extent and having the maximum storage coefficient to about $640,000 \mathrm{ft}$ for a confined aquifer with only a $0.5 \mathrm{mi}^{2}$ areal extent and having the minimum storage coefficient. For a flow augmentation rate of $10 \mathrm{ft}^{3} / \mathrm{s}$ that requires a recharge water volume of 2,871 acre-ft, the necessary change in head ranges from about $37 \mathrm{ft}$ for an aquifer with a $20 \mathrm{mi}^{2}$ areal extent and having the maximum storage coefficient to about $6,400,000$ $\mathrm{ft}$ for a confined aquifer with only a $0.5 \mathrm{mi}^{2}$ areal extent and having the minimum storage coefficient. From these results, it can be seen that large head changes across extensive areas are required to store or yield substantial quantities of water from the Grande Ronde aquifer under confined conditions. For comparison, the low-lying part of the Milk Creek sub-area is less than $1 \mathrm{mi}^{2}$.

Using $100 \mathrm{lb} / \mathrm{in}^{2}$ as the practical upper limit for injecting water under pressure (Brett Moore, Anderson Perry and Associates, Inc., written commun., 2014) and a value of $2.31 \mathrm{ft}$ of head per lb/in ${ }^{2}$ (Lohman, 1972, p. 9) results in a practical upper limit of $231 \mathrm{ft}$ of head for injecting under pressure. Using the minimum, median, and maximum values of the storage coefficient for the Grande Ronde aquifer, the aquifer surface area required would be 1,$400 ; 3.7$; and $0.32 \mathrm{mi}^{2}$, respectively, for a flow augmentation rate of $1 \mathrm{ft}^{3} / \mathrm{s}$ that requires a recharge water volume of 287 acre- $\mathrm{ft}$. Aquifer surface areas of 14,000; 37; and $3.2 \mathrm{mi}^{2}$, respectively, would be required for a flow augmentation rate of $10 \mathrm{ft}^{3} / \mathrm{s}$ that requires a recharge water volume of 2,871 acre-ft. A graph of the relation between the aquifer-surface area and the storage coefficient is shown in appendix B, figure B5.

A discussion on the ability of the MUS system to economically store and recover water in a confined aquifer is important to the determining the feasibility of the proposed MUS project, as is obtaining accurate estimates of the storage coefficient and areal extent of the aquifer.

Hydrogeology, p. 3-7, third paragraph.- The statement in this paragraph mentions that the effects of a negative boundary were identified after the first 100 minutes of a 24-hour aquifer test. However, a negative boundary also was identified after the first 16 minutes of the aquifer test (James M. Montgomery Consulting Engineers, Inc., 1992, p. C-38). This suggests that at least two negative boundaries are present in basalt aquifer near the test well. As cited in the James M. Montgomery Consulting Engineers report on the aquifer test results:

As the radius of influence encountered these negative boundaries, drawdown increased. The flow boundaries reduce the calculated, or apparent, transmissivities by as much as an order of magnitude from the initial calculated [transmissivity] ... The net effect of the boundaries is a significant reduction in long-term well yield in comparison to the short-term well yield.

The 24-hour aquifer test conducted at Milk Creek was on the 170-ft-deep well, UNIO 2176, completed in the basalt aquifer. A second, 540-ft-deep well, UNIO 2192, was completed in the basalt aquifer in this area about 4 months later, perhaps as part of the recommendations in the report by James M. Montgomery Consulting Engineers, Inc. (1992, p. C-46). The driller's log for the well is contained in the appendix of the subject report and indicates decreased flow rates from 100 or more gallons per minute to 10 or more gallons per minute as the depth of the well increased from 125 to $320 \mathrm{ft}$ during drilling. This reduction in flow rate with depth is difficult to interpret without knowing the conditions at the time of the measurements, including well construction, casing, drill stem in place, and other factors. As noted in the feasibility study, additional aquifer testing is needed. A 24-hour, or preferably longerterm, aquifer test on existing and new wells would be extremely useful in helping to determine the hydraulic properties of the aquifer, the effects of negative boundaries (if present), and the suitability of the well and aquifer for an MUS system. 
Hydrogeology, p. 3-8, first paragraph, and p. 3-8 table titled "Aquifer characteristics and Well Capacities-Columbia River Basalt Aquifers".- As noted for the table for the alluvial aquifer wells, it would be helpful if this table showed the number of wells used for evaluation of each sub-area. It seems that only four well logs presented in appendix $C$ of the study, according to the text, were used to determine aquifer characteristics. For the table, two wells are near the Union sub-area, two wells are near Milk Creek sub-area, no wells are near the Badger Flat sub-area. Depending on the actual number of wells used to determine the table of Columbia River Basalt aquifer characteristics, it may need to be emphasized that a very small number of wells across a large area were used to determine the aquifer characteristics because of the lack of available well data. This may lead to great uncertainty regarding the presence or absence of the aquifer and regarding aquifer characteristics.

Hydrogeology, p. 3-8, second paragraph.-This paragraph discusses the possible productivity of the Grande Ronde aquifer and the occurrence of flowing artesian conditions, and includes this statement: "In the longer term, recharge of the aquifer and recovery to enhance stream flows could be implemented and would be facilitated by depressurization of the basalt aquifer by prior pumping." However, further discussion should have been included on how this would be implemented and of the possible consequences. Is it feasible to obtain the water rights and permits necessary to first pump the basalt aquifer during the first irrigation season to be subsequently recharged the following winter? After the initial depressurization of the basalt aquifer and possible change from artesian to non-artesian conditions, or possibly even from confined to unconfined aquifer conditions, the MUS system then might have the available headroom needed for storage of water during the winter for use during the following summer. Would this be less expensive and more efficient that trying to inject water under pressure for a basalt aquifer that is already artesian at the beginning of the winter flows? Would the storage and transmissivity characteristics of the aquifer be such that the cone of depression would diminish from adjacent flow from the aquifer prior to the ability to use water from upper Catherine Creek? An analysis of water and aquifer storage requirements is provided in appendix B of this review, which includes a discussion of unconfined aquifer conditions. Additional discussion is needed to address these questions and, most likely, so is the collection of additional data such as estimates of the areal extent and specific yield of the aquifer.

Summary, p. 3-9, third paragraph. - It is important to include in the Summary the following three conditions identified in this section: (1) the flowing artesian conditions in the basalt aquifer in the Milk Creek sub-area may limit the available storage and may require wellhead equipment designed for water injection under pressure; (2) as indicated by the results of the 24-hour aquifer test in the Milk Creek sub-area (see p. 3-7, paragraph 3, of the subject report), low-permeability boundaries were observed for the basalt aquifer, and these boundaries may be a limiting factor and require further evaluation to determine the potential for groundwater production and recharge in this area; and (3) the small number of available wells for analysis in the Milk Creek sub-area creates a large uncertainty regarding the extent, thickness, and hydraulic properties of the basalt that will require further analysis to determine the suitability of the aquifer in the area for use in an MUS system. 


\section{Section 4-Water Quality Evaluation}

General, p. 4-1, second paragraph.-As stated in this paragraph, the available water-quality data for Catherine Creek and native groundwater are "sparsely distributed and incomplete, and the sample locations are not located specifically in the area(s) where MUS may be implemented." It is, therefore, difficult to evaluate much of the remaining parts of this section. However, the recommendations in the section to fill existing data gaps are appropriate and generally cover the areas where additional information is needed either to meet regulatory considerations or to better predict performance of the MUS system with regard to geochemical compatibility of the surface water and groundwater within the aquifer matrix.

Regulatory Considerations, p. 4-2, first and second paragraphs.-No mention is made of water temperature in the evaluation of water-quality data. Water temperature may be of regulatory concern with regard to Upper Grande Ronde River subbasin TMDL (Oregon Department of Environmental Quality, 2000a, 2000b, 2000c) or of concern with regard to other possible environmental effects, both negative and positive. Low temperature geothermal springs and wells with temperatures ranging from 68 to $185^{\circ} \mathrm{F}$ have been identified within the Grande Ronde Valley (Ferns and others, 2010 , p. 50). A relatively wide range of temperatures $\left(50-72^{\circ} \mathrm{F}\right)$ is indicated in table $4-1$ in the subject report and several of the drillers' logs for the basalt wells in the appendix $C$ of the subject report. In the Milk Creek sub-area, the 170-ft-deep basalt well (UNIO 2176) had a temperature that remained constant at $50^{\circ} \mathrm{F}$ during a 24-hour aquifer test (James M. Montgomery Consulting Engineers, Inc., 1992, p. C38). However, the driller's log for the 540-ft-deep basalt well (UNIO 2192) in the Milk Creek sub-area had a temperature of $59^{\circ} \mathrm{F}$, indicating greater temperatures with depth as would be expected because of the geothermal gradient. Figure 2 was created for this review using wells greater than $350 \mathrm{ft}$ deep within about $8 \mathrm{mi}$ of the Milk Creek sub-area to help depict the variation in water temperature with well depth using drillers' logs available from the OWRD (Oregon Water Resources Department, 2014b). Note that water temperatures as high as $81^{\circ} \mathrm{F}$ have been reported. A negative effect on Catherine Creek could occur if discharge water from the MUS system during the irrigation season had a temperature that is greater than the temperature of Catherine Creek, potentially harming aquatic species and perhaps violating the TMDL. A positive effect on Catherine Creek could occur if the temperature of the discharge water were less than the temperature of Catherine Creek, possibly providing cold-water refugia for aquatic species and reducing the potential for violation of the TMDL downstream.

The water temperatures reported for Catherine Creek shown in table 4-1 should be broken down by season because the temperature difference may be of concern with regard to the injection and withdrawal of water from and to Catherine Creek at different times of year. Data on and analyses of water temperatures for Catherine Creek and some of its tributaries from reports by the Oregon Department of Environmental Quality (2000a, 2000b, and 2000c) may be useful for comparison. 


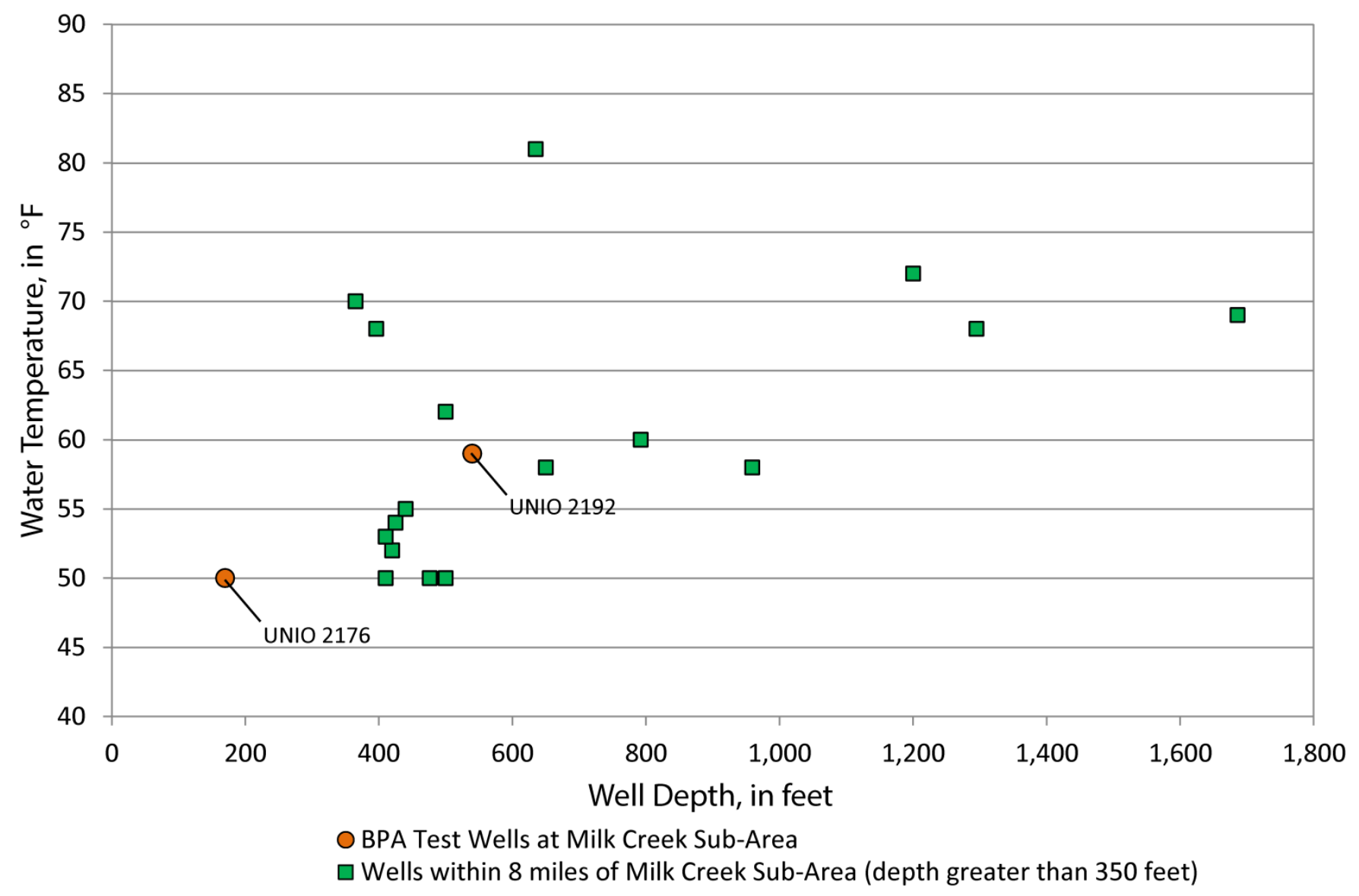

Figure 2. Graph showing water temperature and well depth for wells within about 8 miles of the Milk Creek subarea (depths greater than 350 feet), upper Catherine Creek watershed, Union County, northeastern Oregon. (Source: Oregon Water Resources Department Well Log Query Web page, accessed January 3, 2014, at http://apps.wrd.state.or.us/apps/gw/well_log/).

Recovered Water Quality, p. 4-7, fifth paragraph.-The method proposed to create a buffer of good-quality source water in the aquifer (see following quotation) should include a statement that this would require either an increase in the quantity of surface water diverted for recharge of the aquifer or a reduction in the quantity of water discharged from the aquifer for supplementing streamflow. In either case, the cost per acre-foot of water of the MUS system would be increased. This additional volume of water would need to be stored in the aquifer and should be included in any calculations of aquifer storage requirements.

Management of water quality issues in native groundwater when AR or ASR is utilized can sometimes be achieved by retaining a portion of stored source water in the aquifer to create a "buffer" of good quality source water during the first several years of storage. This is a management technique that could be utilized if site-specific concentrations of fluoride (or other constituents) in native groundwater are of concern to fish. 


\section{Section 5-Existing Infrastructure}

ASR/AR INFRASTRUCTURE COMPONENTS, p. 5-1.-Discussion is needed of the possible infrastructure needs for treatment with regard to water temperature for either recharge or recovery, if temperature is determined to be an issue. Additional discussion also is needed to address the special infrastructure requirements in the Milk Creek sub-area, where flowing artesian conditions were observed in the two existing wells in this area.

\section{Section 6-Existing Water Rights}

General, p. 6-1, first paragraph.-It may be necessary to evaluate the water rights downstream of the Upper Davis and Davis Dams (fig. 1) to the confluence of Catherine Creek with the Grande Ronde River to ensure that any potential acquisition of water associated with water rights upstream of the Davis Dams would not be diverted by senior water-rights holders, reducing the goal of increasing instream flows in Catherine Creek. A discussion of the viability of acquiring a senior water right near the confluence of Catherine Creek with the Grande Ronde River (to ensure passage of water through the entire length of Catherine Creek) and the potential cost of such acquisition would be helpful to decision makers.

Summary, p. 6-2, second paragraph.-The potential for the purchase of a senior water right as a cost-effective means to ensure $1 \mathrm{ft}^{3} / \mathrm{s}$ of flow in Catherine Creek seems to be underemphasized. This is a major conclusion and should be included in the Executive Summary.

\section{Section 7-Permitting Requirements}

Source Water and Water Use Permitting, p. 7-3, third paragraph.—The statement_- "In the early 1990s, OWRD reserved 9,000 acre-ft of un-appropriated water from Catherine Creek above Ames Creek for storage uses (OAR 690-508-0120), which includes AR but not ASR" —is inconsistent with the following statement in Section 9-MUS Feasibility Evaluation-Evaluation of Key Feasibility Factors, p. 9-2, first paragraph: "An additional 9,150 AF above Ames Creek has been reserved by the state for multipurpose storage in the months of January through April, October, and December." The correct value should be determined and the text and figures should be revised for consistency. This may affect figures ES-4 and 9-1, table 2-1, and the table on p. 7-4, Water Available in Catherine Creek for $A R$.

\section{Section 8-Conservation and Efficiency}

General, p. 8-1, first paragraph.-The analysis of conservation and efficiency was straightforward but somewhat simplistic. It is likely that a more thorough and sophisticated analysis was beyond the scope of this study. However, some mention of the difficulty of accurately estimating for the specific area of interest the consumptive use of crops, diversion of water for irrigation, precipitation, inflow from subirrigation, changes in soil-moisture storage, losses to groundwater recharge, and return flow of shallow subsurface runoff to streams would benefit the reader and provide some idea of the uncertainty associated with the estimates made. If available, studies in the Grande Ronde Basin of seepage losses from drainage ditches, crop consumptive use, return flow estimates, and so on conducted by the U.S. Army Corps of Engineers, soil conservation or irrigation districts, or other sources that could provide a greater level of detail. 
Because of the importance of this section of the study and the fact that water-resources management and expenditure of significant financial resources will be based on the analysis and conclusions presented, a more thorough analysis of the potential quantity and cost for conservation and efficiency efforts to increase streamflow in Catherine Creek should be considered.

Irrigation Systems, p. 8-1, fourth paragraph.- The discussion of the estimation of average irrigation required in the upper Catherine Creek area does not mention the possible input from soilmoisture storage, which likely is most significant during the early spring. Depending on antecedent conditions (precipitation and evapotranspiration prior to the start of the irrigation season), this could be a substantial quantity of water. Additionally, some discussion is warranted regarding subsurface return flow of excess irrigation water to adjacent streams that can be a significant source of water to the streams. The implementation of high-efficiency irrigation systems may reduce diversions but also may reduce return flows used by downstream users or as instream flows and may provide less net benefit.

Efficiency and Conservation Capabilities, p. 8-3, third paragraph. - It is unclear where the value of $80 \mathrm{ft}^{3} / \mathrm{s}$ was obtained for the calculated water-use reduction for a 4-month irrigation season. About $44.6 \mathrm{ft}^{3} / \mathrm{s}$ owing to seepage and evapotranspiration losses is easily calculated using the information provided in the section Water Conveyance. However, the method of calculation of the savings from irrigation efficiency (that must total to the remaining $35.4 \mathrm{ft}^{3} / \mathrm{s}$ ) is not evident and should be described.

Efficiency and Conservation Capabilities, p. 8-3, third paragraph.- The actual quantity of water used for irrigation downstream of OWRD stream gage 13320300 and upstream of the Upper Davis and Davis Dams (fig. 1) may be considerably less than the surface-water rights cited in this paragraph as "130 cfs to supply existing unmet irrigation water rights" and that was previously described in Section 2, p. 2-2, second paragraph, as "OWRD Stream Gauge Site 13320300 is located upstream of four diversions (including the Davis Dams) with a total of $131.01 \mathrm{cfs}$ of surface water rights...". Using a simple calculation, over a 4-month period, this is about 55,000 acre-ft of water. Using the value of 7,000 acres (cited on $p$. 8-3, second paragraph) for the surface-water irrigation in this area yields a water depth of about $7.9 \mathrm{ft}$ (95 in.). Using $31.83 \mathrm{in}$. for "Net Irrigation Required" from the table on $p$. 8-1 and assuming a 50 percent efficiency for current irrigation practices yields an actual water use of about 64 in. needed for irrigation. The difference between the water right and actual water use is about $31 \mathrm{in}$. of water, indicating that about 33 percent of the water right goes unused. For the 130 $\mathrm{ft}^{3} / \mathrm{s}$ of water rights for this area, the amount of unused water could be as much as about $43 \mathrm{ft}^{3} / \mathrm{s}$ and could be higher if greater efficiencies are assumed. The acquisition of the unused portion of the water rights, especially from senior water-rights holders that are located as far as possible downstream on Catherine Creek, should be considered.

More accurate estimates of consumptive use of water could be obtained using remote-sensing methods such as METRIC (Allen and others, 2007a, 2007b) to determine actual evapotranspiration at grid resolutions of $30 \mathrm{~m}$ (see Snyder and others, 2012, p. 5, for example). This information could be used in conjunction with water-rights maps of places of use and points of diversion to associate the water right with an estimate of water use (after accounting for precipitation, subirrigation from shallow groundwater, irrigation groundwater, and return flow). This would help distinguish water rights that either are not being used or are being under-used to find potentially willing sellers for all or a portion of their water right or to participate in the OWRD Allocation of Conserved Water Program. 
Efficiency and Conservation Capabilities, p. 8-3, fourth paragraph.-The OWRD

Allocation of Conserved Water Program is described in this paragraph of the subject report as follows:

Currently, the State will retain at least 25 percent of water saved due to incentives for water use efficiency under Statutes and Oregon Administrative Rules associated with Oregon's Conserved Water Program (ORS 537.470(3)). If more than 25 percent of the funds used to finance the conservation measures comes from federal or state public sources and is not subject to repayment, the percentage of water allocated to the State is equal to the percentage of public funds used to finance the conservation measures (ORS 537.470(3)). The water right holder may always choose to retain up to 25 percent of the conserved water (ORS 537.470(3)). Enhanced in-stream flow is dependent on a water right holder's willingness to participate in the Conserved Water Program, the source of funding for conservation and efficiency measures, and their willingness to transfer up to 75 percent of the water saved to the State.

However, it fails to state the following condition that can be applied to the conserved water:

A new water right certificate is issued with the original priority date reflecting the reduced quantity of water being used with the improved technology. Other certificates are issued for the applicant's portion of the conserved water and for the state's instream water right. The priority dates for these certificates are either the same as the original right, or one minute junior. (ORS 537.485 and OAR 690-18). (Oregon Secretary of State, 2014; Oregon State Legislature, 2014a; Oregon Water Resources Department, 2014a)

If senior water-rights holders with points of diversion and place of use near the confluence of Catherine Creek and the Grande Ronde River are targeted for participation, and possibly provided with incentives, then the instream water rights acquired by the State could have a priority date that is the same as the original priority date. This could help ensure that the conserved quantity of water would be protected from diversion upstream of water-rights holders with lessor priority dates. It would no longer be necessary to obtain an additional $130 \mathrm{ft}^{3} / \mathrm{s}$ of instream flow to meet the needs of water-rights holders upstream. Only $1-10 \mathrm{ft}^{3} / \mathrm{s}$ of instream water rights would need to be acquired. This could be a costeffective solution to meeting the inflow stream goals of the subject report.

Summary, p. 8-3, fifth paragraph.-See comments under review section, "Executive Summary-Conservation and Efficiency, p. ES-5, second paragraph."

Additionally, in the statement quoted from the subject report, the cost of the upper range of $\$ 30,000,000$ may be miscalculated. The upper range actually may be only $\$ 25,200,000$, as calculated using the sum of $\$ 1,200$ per acre $\times 5,600$ acres and $\$ 100$ per $\mathrm{ft} \times 35 \mathrm{mi}(184,800 \mathrm{ft})$, using the quoted rates from this paragraph of the subject report:

The cost to upgrade 100 acres from flood irrigation to an efficient sprinkler system could be as high as \$1, 200 per acre. The cost to install piping could be as high as $\$ 50$ to $\$ 100$ per foot. The cost for efficient irrigation infrastructure could be in the range of $\$ 15,000,000$ to $\$ 30,000,000$ before the cost of operation and maintenance is considered.

Because of the importance of the estimates of the efficiency and conservation measures, it is essential that the quoted rates have an associated citation. Only with attribution to reputable sources can the validity of such estimates be evaluated by the reader and a determination made as to whether the estimates are reasonable and appropriate for the area of the Grande Ronde Basin.

It should be noted that, on $p$. 6-2 of the subject report, the value of the agricultural land is listed as $\$ 2,000$ per acre. Therefore, the 7,000 acres irrigated with surface water in this area (cited on p. 8-3, 
second paragraph) could be purchased at a cost of $\$ 14,000,000$, assuming willing sellers. This could be a cost-effective solution to reducing the quantity of appropriated water.

The statement_ - "Efficiency and conservation have the potential to provide increased irrigation to a larger number of water users for a longer period of the irrigation season; however, they do not have the potential to provide stream flow enhancement for fish passage and stream health" — is not accurate with regard to the provisions of ORS 537.470(3), as noted in the discussion of "Efficiency and Conservation Capabilities, p. 8-3, fourth paragraph."

A cost-benefit analysis using cost per acre-foot of water or per cubic foot per second of water for a specified duration would help decision makers better compare options to increase streamflow in Catherine Creek.

Section 9-MUS Feasibility Evaluation

Project Implementation Plan, p. 9-9, second paragraph.--Under the Project Implementation Plan is the following task:

Confirm whether the OWRD will support the approach of defining the place of use at the mouth of Catherine Creek and using a secondary permit to shuttle water from the Milk Creek sub-area to the place of use to protect stream flows enhanced by implementation of the MUS alternative from appropriation by downstream users.

Because of its importance, the Project Implementation Plan should make this task a high priority as the success of the project seems to hinge on this determination. It would make little sense to proceed with other tasks until this issue has been resolved. Additionally, the cost of this task may be small compared to the cost of other tasks. Informal discussions with the OWRD for this review indicate that it may be possible to use the proposed method of shuttling water to ensure that water recovered from the MUS system remains in Catherine Creek without diversion from senior water-rights holders all the way to the confluence of the Grande Ronde River, described as follows (excerpted from Section 7, p. 7-7, paragraph 3):

[The MUS project could potentially] utilize a process implemented by downstream users of stored water in reservoirs that use a stream to shuttle water from the reservoir to their point of diversion. This "shuttled" water is protected (ORS 540.410) from diversion by other water users in between the reservoir and the intended recipient of the water. This option would likely be available only if a secondary groundwater permit for AR was utilized with a point of diversion at the location where stored water entered Catherine Creek and a place of use designated at a point downstream, presumably at or near the confluence of Catherine Creek and the Grande Ronde River. This would presumably provide protection of the water from diversion by other surface water users (including senior water right holders) between the location where stored water entered Catherine Creek to the location defined as where the wildlife and fish life benefit was to be used (the place of use). [Oregon State Legislature, 2014b]

This section does not discuss alternatives to protecting water discharged by the MUS system from diversion by other water users in the event that the water cannot be "shuttled" and protected pursuant to ORS 540.410 .

\section{Section 10-Environmental Impact}

Wetlands, p. 10-2, sixth paragraph.-There is no mention of the effects of possible groundwater-level changes associated with operation of the MUS system on wetlands identified in the project area. If there is an interconnection between the surficial alluvial aquifer in which the wetlands 
are located and the underlying basalt aquifer, then groundwater-level changes associated with the operation of the MUS system might be expected. Discussion should have included the potential for groundwater-level declines owing to pre-pumping of the basalt aquifer to partially dewater it in preparation for it to receive recharge water should those declines propagate into the surficial aquifer and affect nearby wetlands. Additional discussion is needed of the potential for groundwater-level increases owing to recharge of the aquifer, especially if artesian pressures are increased, and how this might propagate through the surficial aquifer and affect the wetlands. It would be useful to have continuous water-level recorders in the alluvial aquifer, basalt aquifer, and Catherine Creek to determine the possible interconnection of the alluvial aquifer, the basalt aquifer, and Catherine Creek that, if present, then could be used to determine the possible magnitude of water-level changes and the effect on the wetlands in the area.

Water Quality, p. 10-4, third paragraph.-The potential effect of the MUS system on stream temperature is not mentioned. This concern is discussed in this review under "Section 4-Water Quality Evaluation-Regulatory Considerations, p. 4-2, first and second paragraphs.”

Miscellaneous Issues, p. 10-5, supplemental.-The possible environmental effects of storing water in a confined aquifer should be discussed. If the basalt aquifer is confined, this may necessitate increasing the pressure in the aquifer to accommodate the storage of the target recharge water volumes for the MUS system. The increase in pressure would raise the head in the aquifer and might cause many previously non-flowing wells to begin to flow at land surface. The hydraulic gradient between the basalt aquifer and the overlying alluvial aquifer also would change, possibly increasing the upward vertical flow of water into the alluvial aquifer, raising groundwater levels, and perhaps increasing discharge to wetlands or increasing base-flow discharge to Catherine Creek at unintended times.

Section 10-Environmental Impact should include a brief discussion of the effect of possible compartmentalization of the aquifer because of aquifer geometry or structural features previously discussed in this review. Compartmentalization, if present in the aquifer affected by the MUS system, could limit the spatial extent to which environmental effects (if any) from the MUS system are experienced. However, within the areas of compartmentalization, the environmental effects, either detrimental or beneficial, could be accentuated because they would be confined to a smaller area. Further data and analysis are necessary to determine what types of environmental effects might occur and their severity.

\section{Additional Comments}

Questions Not Addressed in the Feasibility Study.- Several questions not addressed in the feasibility study are presented here. It is outside the scope of this review to determine if such considerations should be included in the feasibility study.

- If the MUS system were to be implemented and relied upon to provide additional flow to Catherine Creek, what would the consequences be if (1) there were a catastrophic failure of the MUS system; (2) the MUS system provided less water than anticipated, or the amount of water diminished over time; or (3) the MUS system was determined to be prohibitively expensive to operate and maintain?

- How does the ability of an MUS system to reliably provide supplemental flows compare to the ability of a conservation and efficiency program or the acquisition of water rights to reliably reduce diversions? 
- Does an analysis need to be done to determine the vulnerability and likelihood that the MUS operations may be interrupted or infrastructure may be damaged from hazards such as floods, landslides, forest fires, or other perils? As mentioned in the subject report, the location for the preferred alternative is within a 100-year flood zone (Section 10, p. 10-2, fifth paragraph). The Oregon Hazards Explorer (Oregon State University Libraries, 2013) indicates a high wildfire risk for most of the area at this location. The Oregon Hazards Explorer also indicates that, although no landslides are mapped at the location, several landslides have been mapped upstream and downstream along Catherine Creek. Each of these hazards may pose a risk to the MUS system, either directly, through damage to the infrastructure, or indirectly, by affecting operations such as alteration of channels or deterioration in water quality or turbidity.

\section{Specific Issues of Minor Concern}

This section contains comments on issues that were considered of minor concern regarding the data, analyses, interpretations, or conclusions in the report. It is provided here as an aid to improve reader understanding of the report, to resolve some discrepancies, and to improve future versions of the feasibility analysis. The section is organized by each section of the subject report, and each comment is preceded by the section location and context.

Executive Summary, Section 2-Existing Stream Flows, and Table 2-1.-The number of days used for each month in the conversion of flow rates (in cubic feet per second) to water volumes (in acre-feet) was not always correct or consistent. For example, 31 days were used for February instead of 28 or 28.25 . This may have only a relatively small effect on the values and probably does not change any conclusions. However, the values derived in the subject report of 281and 2,806 acre-ft of water required for the recharge volume for the $1-$ and $10-\mathrm{ft}^{3} / \mathrm{s}$ augmentations, respectively, are incorrect. The correct values would be $244 \mathrm{ft}^{3} / \mathrm{s} \div 85$ percent $=287$ acre- $\mathrm{ft}$ for the $1-\mathrm{ft}^{3} / \mathrm{s}$ augmentation and $2,440 \mathrm{ft}^{3} / \mathrm{s}$ $\div 85$ percent $=2,871$ acre-ft for the $10-\mathrm{ft}^{3} / \mathrm{s}$ augmentation (where the 85 percent is the permitted recovery according to OWRD). It will be important to have the correct values for any permits or waterrights applications that are made. Using the required diversion volumes shown here for the 1- and 10$\mathrm{ft}^{3} / \mathrm{s}$ augmentation and the number of days in the 5- and 7-month recharge periods of 151 and 212 days, respectively, the required recharge rates are 0.68 and $0.96 \mathrm{ft}^{3} / \mathrm{s}$, respectively, for 5- and 7-month recharge periods for the $1-\mathrm{ft}^{3} / \mathrm{s}$ augmentation, and 6.8 and $9.6 \mathrm{ft}^{3} / \mathrm{s}$, respectively, for 5 - and 7 -month recharge periods for the $10-\mathrm{ft}^{3} / \mathrm{s}$ augmentation.

Additionally, the total volume of 9,150 acre-ft derived in the subject report slightly exceeds the 9,000 acre-ft "storage reservation only" (described on p. 7-3, third paragraph) because of this error. Using the flow rates as shown in table 2-1 for "Storage Reservation Only under Water Availability in Catherine Creek," the volume of water is actually 8,987 acre-ft, which does not exceed the limit of 9,000 acre-ft. This should be corrected before submission of the water-use permit request to access this water. Note that the value of 9,150 acre-ft also is used in figures ES-4 and 9-1, and may require correction if the recommended change is made to table 2-1. See "Section 7-Permitting Requirements - p. 7-4, table titled "Water Available in Catherine Creek for AR" in this review for a similar issue. The entire table 2-1 should be recalculated to correct these errors.

Executive Summary, Figure ES-2 and Section 2-Existing Stream Flows, Figure 2-2-The highest and lowest flows for the period of record for OWRD stream gage 13320300 are shown in this figure. It would be helpful to see a graph showing the statistical distribution of flows or perhaps even a 
figure showing all flows on record. This type of information would be helpful in determining what the typical hydrograph looks like and the type of variation that occurs. Two figures were created for this review to show this and to better depict the streamflow records for Catherine Creek. All the yearly hydrographs using daily mean streamflow from 1997 to 2007 (with the mean daily streamflow overlaid for comparison) are shown in figure 3 . The daily mean streamflow for individual dates at this siteusing 0 (maximum streamflow), 10, 25, 50 (median streamflow), 75, 90, and 100 (minimum streamflow) percentiles - are shown in figure 4, using the data available from the OWRD Hydrographics Database (Oregon Water Resources Department, 2013c). This provides the reader with a better understanding of what percentage of the time a certain flow can be expected to be exceeded on a specific date. Together, figures 3 and 4 may be more useful than the hydrographs of daily mean streamflows for average, historical high, and historical low years for the period of record, as provided in figures 2-1 and 2-2 of the feasibility study report, respectively.

Section 7-Permitting Requirements-p. 7-4, table titled "Water Available in Catherine Creek for AR".- -Some values in this table are incorrect, as discussed in this review in the comments for "Executive Summary, Section 2-Existing Stream Flows, and Table 2-1."

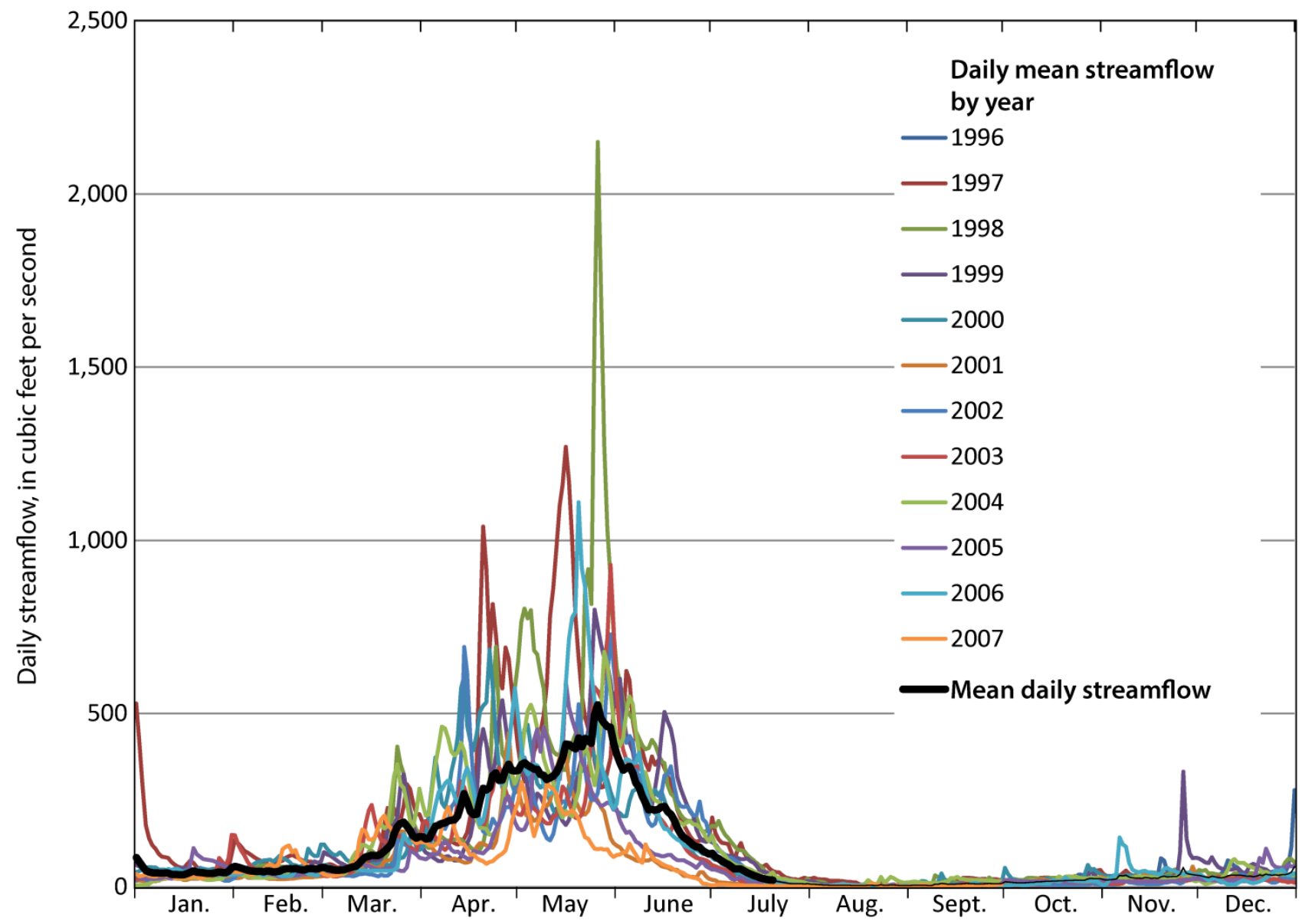

Figure 3. Graph showing daily mean streamflows, by year, and mean daily streamflow, at Oregon Water Resources Department stream gage 13320300 (based on daily mean discharge), Catherine Creek, Union County, northeastern Oregon, October 1997-September 2007. 


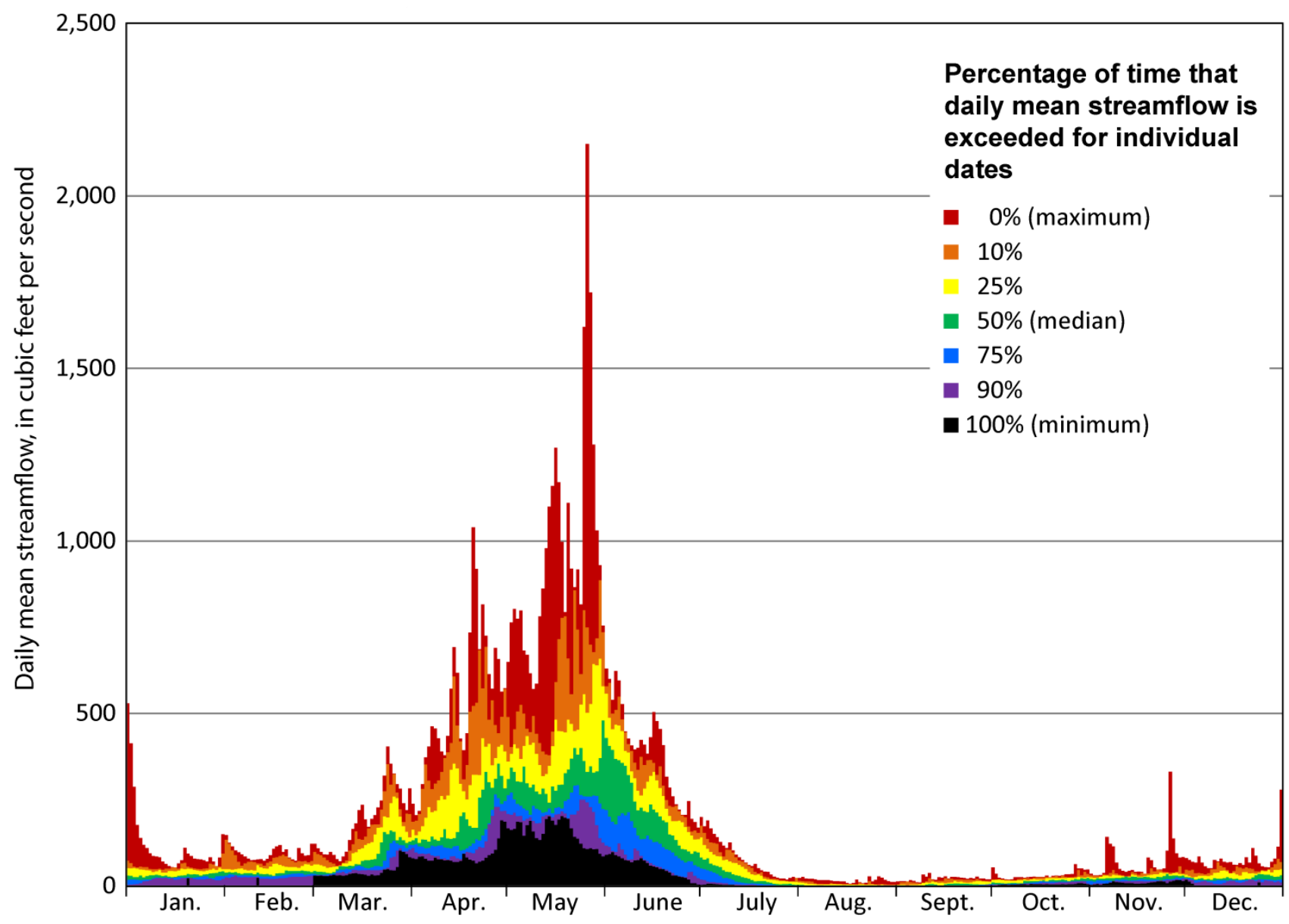

Figure 4. Graph showing percentiles of daily mean streamflow for individual dates, at Oregon Water Resources Department stream gage 13320300 (based on daily mean discharge), Catherine Creek, Union County, northeastern Oregon, October 1997-September 2007.

\section{Information Needs}

This section presents data gaps and information needs (either previously identified in the subject report or as part of the present review) that are of particular importance. Each comment is preceded by its location and context.

\section{Executive Summary and Section 4-Water Quality Evaluation-General, p. 4-1, second} paragraph (also stated in Executive Summary, p. ES-3, third paragraph) and Evaluation of Water Quality Data, p. 4-4, fourth paragraph.-These sections include the following two statements: (1) "Because existing water quality data sets for Catherine Creek (potential source water) and native groundwater are sparsely distributed and incomplete, and the sample locations are not located specifically in the area(s) where MUS may be implemented for stream flow enhancement, a detailed water quality analysis relative to the listed feasibility criteria was not possible," and (2) "It is important to note that available data from Catherine Creek do not include analysis for most metals, volatile organic compounds (VOCs), and synthetic organic compounds (SOCs); consequently, assessment of the potential for degradation of the storage aquifer by these constituents is not possible." These statements 
underscore the need for the acquisition of water-quality data to facilitate analysis of the geochemical interaction between the source surface water, native groundwater, and the aquifer matrix. These interactions could affect the quality of the water in the aquifer or water discharged to Catherine Creek, as well as the performance of the MUS system.

Section 3-Hydrogeologic Setting-Geologic Units, p. 3-3, second paragraph. - The feasibility study states: "...the total thickness of the CRBG [Columbia River Basalt Group] in the vicinity of Union is unknown." This information is needed to better evaluate the extent and thickness of the aquifer to determine the available aquifer volume and, therefore, the quantity of water that can be stored using MUS. This information also will be useful in determining if current wells, considering the segment of aquifer during drilling, are adequate to describe the hydrologic characteristics of the entire aquifer, or if new wells that intercept a larger segment of the aquifer are needed.

Geologic Structures, p. 3-3, fifth paragraph.- The lack of available wells near the project area and the associated information contained in the drillers' logs represents a significant data limitation with regard to determining the presence of geologic structures and their effect on the hydrogeology of the area, and on how the MUS system might perform. As well stated in the subject report:

Faults and steep folds can modify the hydraulic behavior of volcanics-hosted aquifers, most notably the CRBG. These structures have the potential to impede or enhance lateral and vertical movement of groundwater, potentially creating negative or positive hydrogeologic boundaries. Negative boundaries may limit the rate and volume of water that can be stored and/or recovered from a well. The area of a fault-bounded basalt block may directly influence storage volume in a particular basalt flow sequence and may cause excessive head buildup during injection and groundwater discharge at the surface where basalt interflows are exposed or vertical pathways occur.

Hydrogeology, p. 3-7, first paragraph.-A volumetric analysis of the quantity of water to be stored in the aquifer and the volume of aquifer necessary to accommodate the volume of water using a range of possible values of storage coefficients and aquifer dimensions is required to determine available headroom, infrastructure needs, costs, potential environmental effects, and implications regarding the feasibility of the MUS system. Estimates are needed of the specific yield, storage coefficient, and areal extent of the aquifer. A determination also is needed to ascertain if the Grande Ronde aquifer is confined or unconfined throughout the area expected to be used for the MUS system.

Hydrogeology, p. 3-8, first paragraph.- The lack of available data with regard to the extent, thickness, and character of the hydrogeologic units in the Milk Creek sub-area, selected as the primary target for an MUS system, is one of the largest data gaps. The feasibility study states: "Due to the highly faulted nature of the area, depths and thicknesses of units vary significantly and estimates are not well constrained. Estimates of depths to the CRBG aquifers are based on limited data: well logs, geologic maps, and structural geologic information."

The hydrogeologic analysis of the Milk Creek sub-area used only two wells located relatively near each other. From a review of the OWRD GRID database of well records, these seem to be the only wells in this area. The feasibility study was limited to using existing data and appropriately indicated the importance of additional data collection. However, the reliance on such a small number of wells for the identification of an area for an MUS system is not ideal. The geometry (extent and thickness) of the geologic units in this area is complex, as is the lithology, making it challenging to readily determine the geologic units present in the target area. It also is difficult to evaluate the hydraulic properties of the 
target aquifer (Grande Ronde aquifer) in this area and to determine the amount of variation that may be present. The extensive number of geologic structures, especially faults, mapped in this area adds to the complexity of evaluating the hydrogeology. The small number of drillers' logs for wells in this area limit the availability of lithologic descriptions, water levels, water temperatures, and other observations that otherwise would be helpful to determine the influence of these structures on the hydrogeology and what effect they may have on the performance of the MUS system. In other areas of the Columbia Plateau, such structures have been shown to compartmentalize and isolate parts of the aquifer (Ferns and others, 2010, p. 51; Burns and others, 2012). This could limit the ability of the MUS system to store and recover water.

Hydrogeology, p. 3-7, third paragraph.-_Long-term aquifer testing of the shallow and deep parts of the basalt aquifer in the Milk Creek sub-area are necessary to quantify the presence and effect of negative boundaries identified during previous short-term aquifer testing and to determine if additional negative boundaries are present and what effect they may have on the planned MUS system.

Section 4-Water Quality Evaluation.-Data gaps generally are presented and well discussed throughout this section of the subject report and are included in the Summary sub-section of the report. However, there is no mention of water temperature in the evaluation of water-quality data. Should field data collection be initiated to further evaluate the feasibility of MUS, the following steps should be considered to fill data gaps with regard to temperature of the surface water during planned periods for diversion for recharge of the aquifer and for the periods where discharge from the aquifer would be used to supplement surface-water flow:

1. Install continuous stream stage-discharge and temperature gages near the potential MUS system in the Milk Creek sub-area upstream and downstream of the planned diversion site.

2. Begin continuous monitoring of water levels and down-hole temperature in the alluvial and basalt wells in the Milk Creek sub-area.

3. Include continuous monitoring of discharge temperature of water produced from the well in future aquifer tests.

Section 8-Conservation and Efficiency-Efficiency and Conservation Capabilities, p. 8-3, third paragraph.-Accurate estimates of consumptive use of water could be obtained using remotesensing methods such as METRIC (Allen and others, 2007a, 2007b) to determine actual evapotranspiration at grid resolutions of $30 \mathrm{~m}$ (see Snyder and others, 2012, p. 5, for example). As discussed in this review under "Specific Issues of Major Concern," this method can be used to distinguish those water rights that are not being used, are being under-used, or are being over-used. This could be useful to identify potential participants for the OWRD Allocation of Conserved Water Program or for enforcement purposes by OWRD for possible modification of water rights based on actual usage. 


\section{Selected References}

Allen, R.G., Tasumi, Masahiro, and Trezza, Ricardo, 2007a, Satellite-based energy balance for mapping evapotranspiration with internalized calibration (METRIC)-Model: Journal of Irrigation and Drainage Engineering, v. 133, no. 4, p. 380-394, accessed March 3, 2014, at http://ascelibrary.org/doi/full/10.1061/\%28ASCE\%2907339437\%282007\%29133\%3A4\%28380\%29.

Allen, R.G., Tasumi, Masahiro, Morse, A.T., Trezza, Ricardo, Wright, J.L., Bastiaanssen, Wim, Kramber, William, Lorite, Ignacio, and Robison, C.W., 2007b, Satellite-based energy balance for mapping evapotranspiration with internalized calibration (METRIC) - Applications: Journal of Irrigation and Drainage Engineering, v. 133, no. 4, p. 395-406, accessed March 3, 2014, at http://ascelibrary.org/doi/abs/10.1061/(ASCE)0733-9437(2007)133\%3A4(395).

Anderson Perry and Associates, Inc., 2010, Upper Catherine Creek storage feasibility study: Prepared for Grande Ronde Model Watershed by Anderson Perry and Associates and GSI Water Solutions, Inc., 141 p., accessed December 30, 2013, at http://www.oregon.gov/owrd/law/docs/GrantApp/GB0015_09Study.pdf.

Burns, E.R., Snyder, D.T., Haynes, J.V., and Waibel, M.S., 2012, Groundwater status and trends for the Columbia Plateau Regional Aquifer System, Washington, Oregon, and Idaho: U.S. Geological Survey Scientific Investigations Report 2012-5261, 52 p., http://pubs.usgs.gov/sir/2012/5261/.

Davies-Smith, A., Bolke, E.L., and Collins, C.A., 1988, Geohydrology and digital simulations of the ground-water flow system in the Umatilla Plateau and Horse Heaven Hills area, Oregon, and Washington: U.S. Geological Survey, Water-Resources Investigations Report 87-4268, 77 p., http://pubs.er.usgs.gov/publication/wri874268.

Drost, B.W., Cox, S.E., and Schurr, K.M., 1997, Changes in ground-water levels and ground-water budgets, from predevelopment to 1986, in parts of the Pasco Basin, Washington: U.S. Geological Survey Water-Resources Investigations Report 96-4086, 172 p., http://pubs.er.usgs.gov/usgspubs/wri/wri964086.

Ferns, M.L., McConnell, V.S., Madin, I.P., and Johnson, J.A., 2010, Geology of the upper Grande Ronde River Basin, Union County, Oregon: Oregon Department of Geology and Mineral Industries Bulletin 107, 65 p., 1 sheet, scale 1:100,000, 1 CD., http://www.oregongeology.org/pubs/B/p-B107.htm.

Fetter, C.W., 1994, Applied hydrogeology (3d ed.): New York, Macmillan College Publishing Company, Inc., $691 \mathrm{p}$.

Freeze, R.A., and Cherry, J.A., 1979, Groundwater: Englewood Cliffs, New Jersey, Prentice-Hall, $604 \mathrm{p}$.

Hansen, A.J., Vaccaro, J.J., and Bauer, H.H., 1994, Ground-water flow simulation of the Columbia Plateau Regional Aquifer System, Washington, Oregon, and Idaho: U.S. Geological Survey WaterResources Investigations Report 91-4187, 101 p., 15 pls., http://pubs.er.usgs.gov/usgspubs/wri/wri914187.

James M. Montgomery Consulting Engineers, Inc., 1992, Preliminary report of test well drilling northeast Oregon hatchery project, U.S. Department of Energy_Bonneville Power AdministrationDivision of Fish and Wildlife, October 1992, in Montgomery Watson, 1995, Northeast Oregon hatchery project, conceptual design report, final report: Report to Bonneville Power Administration, Contract No. 1991BP11466, Project No. 198805300, March 1995, 292 p. (BPA Report DOE/BP11466-1), accessed January 1, 2014, at https://pisces.bpa.gov/release/documents/documentviewer.aspx?doc=11466-1. 
Kahle, S.C., Morgan, D.S., Welch, W.B., Ely, D.M., Hinkle, S.R., Vaccaro, J.J., and Orzol, L.L., 2011, Hydrogeologic framework and hydrologic budget components of the Columbia Plateau Regional Aquifer System, Washington, Oregon, and Idaho: U.S. Geological Survey Scientific Investigations Report 2011-5124, 66 p., http://pubs.usgs.gov/sir/2011/5124.

La Marche, J.L., Wozniak, K.C., Hattan, S.L., and Hackett, J.A., 2013, Groundwater and surface water exchanges in the Catherine Creek Watershed, Oregon: Oregon Water Resources Department Open File Report SW 2013-001, 28 p., accessed May 23, 2014, at http://www.oregon.gov/owrd/PUBS/docs/reports/SW_2013_001_Catherine_Cr_SW_Exchanges_Fina 1_Report.pdf.

Lohman, S.W., 1972, Definitions of selected ground-water terms-Revisions and conceptual refinements: U.S. Geological Survey Water-Supply Paper 1988, 21 p., http://pubs.er.usgs.gov/usgspubs/wsp/wsp1988.

Oregon Department of Environmental Quality, 2000a, Upper Grande Ronde River sub-basin Total Maximum Daily Load (TMDL): Portland, Oregon Department of Environmental Quality_Water Quality Division, April 2000, 76 p., accessed March 2, 2014, at http://iaspub.epa.gov/tmdl_waters10/attains_impaired_waters.tmdl_report?p_tmdl_id=489\&p_report_ type $=\mathrm{T}$.

Oregon Department of Environmental Quality, 2000b, Upper Grande Ronde River sub-basin Total Maximum Daily Load (TMDL)_Appendix A-Temperature analysis: Portland, Oregon Department of Environmental Quality_Water Quality Division, April 2000, 95 p., accessed March 2, 2014, at http://iaspub.epa.gov/tmdl_waters10/attains_impaired_waters.tmdl_report?p_tmdl_id=489\&p_report type $=\mathrm{T}$.

Oregon Department of Environmental Quality, 2000c, Upper Grande Ronde River sub-basin Total Maximum Daily Load (TMDL) — Appendix D_Applicable water quality standards and criteria: Portland, Oregon Department of Environmental Quality_Water Quality Division, April 2000, 8 p., accessed March 7, 2014, at http://iaspub.epa.gov/tmdl_waters10/attains_impaired_waters.tmdl_report?p_tmdl_id=489\&p_report_ type $=\mathrm{T}$.

Oregon Secretary of State, 2014, Oregon Administrative Rules-Water Resources DepartmentDivision 18-Allocation of conserved water: Oregon Secretary of State Web site, accessed March 5, 2014, at http://arcweb.sos.state.or.us/pages/rules/oars_600/oar_690/690_018.html.

Oregon State Legislature, 2014a, Appropriation of water generally (2013 ed.): Oregon State Legislature Web site, accessed March 5, 2014, at http://www.oregonlegislature.gov/bills_laws/lawsstatutes/2013ors537.html.

Oregon State Legislature, 2014b, Chapter 540_Distribution of water; Watermasters; Change in use;

Transfer or forfeiture of water rights (2013 ed.): Oregon State Legislature Web site, accessed March 5, 2014, at http://www.oregonlegislature.gov/bills_laws/lawsstatutes/2013ors540.html.

Oregon State University Libraries, 2013, Oregon hazards explorer: Institute for Natural Resources Web site, accessed December 27, 2013, at http://oregonexplorer.info/hazards.

Oregon Water Resources Department, 2013a, Aquifer storage and recovery: Oregon Water Resources Department Web site, accessed December 30, 2013, at http://www.oregon.gov/owrd/pages/mgmt_asr.aspx.

Oregon Water Resources Department, 2013b, Artificial ground water recharge: Oregon Water Resources Department Web site, accessed December 30, 2013, at http://www.oregon.gov/owrd/pages/mgmt_gw_recharge.aspx. 
Oregon Water Resources Department, 2013c, Hydrographics database-Data access and summary statistics - Catherine Cr at Union, OR: Oregon Water Resources Department Web site, accessed December 17, 2013, at

http://apps.wrd.state.or.us/apps/sw/hydro_report/gage_data_request.aspx?station_nbr=13320300.

Oregon Water Resources Department, 2014a, Allocation of conserved water: Oregon Water Resources Department Web site, accessed March 5, 2014, at http://www.oregon.gov/owrd/pages/mgmt_conserved_water.aspx.

Oregon Water Resources Department, 2014b, Well log query: Oregon Water Resources Department Web site, accessed January 3, 2014, at http://apps.wrd.state.or.us/apps/gw/well_log.

Packard, F.A., Hansen, A.J., Jr., and Bauer, H.H., 1996, Hydrogeology and simulation of flow and the effects of development alternatives on the basalt aquifers of the Horse Heaven Hills, south-central Washington: U.S. Geological Survey Water-Resources Investigations Report 94-4068, 92 p., http://pubs.er.usgs.gov/publication/wri944068.

Snyder, D.T., and Haynes, J.V., 2010, Groundwater conditions during 2009 and changes in groundwater levels from 1984 to 2009, Columbia Plateau Regional Aquifer System, Washington, Oregon, and Idaho: U.S. Geological Survey Scientific Investigations Report 2010-5040, 12 p., http://pubs.usgs.gov/sir/2010/5040/. 


\section{Appendix A. Typographical Errors and Issues of Minor Importance}

This section contains comments on issues that were considered of such minor concern that they did not warrant inclusion in the main body of this review. These comments mostly concern typographical errors or minor inconsistencies that could be confusing to a reader but likely would not change any interpretations or conclusions. They are provided here to enhance reader understanding of the report, to resolve some discrepancies, and to improve future versions of the feasibility analysis. Each comment is preceded by its location and context.

Executive Summary-General p. ES-1, third paragraph; Section 1-General p. 1-1, second paragraph; Section 2-Existing Stream Flows p. 2-1, second paragraph; and Figures ES-1, 1-1, and 1-2. The "Upper Catherine Creek Watershed Boundary" is shown in figures ES-1, 1-1, and 1-2 as consisting of the drainage upstream of the stream gage 13320300 (Catherine Creek at Union), and the "Lower Catherine Creek Watershed Boundary" as consisting of the contributing drainage to the intervening area upstream of the Upper Davis and Davis Dams and downstream of stream gage 13320300. The use of these two names is consistent with the delineations of these two drainage areas as described in Section 2-Existing Stream Flows, p. 2-1, second paragraph, which states: "For the purposes of this study a drainage area was delineated including the Catherine, Pyles, and Little Creek watersheds, as well as a drainage area including only the Catherine Creek watershed, to approximate the amount of water being contributed to Catherine Creek from Pyles and Little Creek." However, this definition is inconsistent with the statements made in the Executive Summary, p. ES-1, third paragraph, and in Section 1, p. 1-1, second paragraph, that "the upper Catherine Creek watershed includes the drainage basin between the Davis Dams, near the city of Union, Oregon, and the Eagle Cap Wilderness."

Note that the terms "Lower Catherine Creek Watershed" or "Lower Catherine Creek Drainage" are not used in the report except in figures ES-1 and 1-1. They are referred to on p. 2-1, second paragraph, although not by name. The terms "Upper Catherine Creek Watershed" and "Upper Catherine Creek Drainage" seem to be used interchangeably in the report. A check should be made to ensure that the terminology referencing the area defined as the Upper Catherine Creek Drainage is consistent throughout the report.

Section 2-p. 2-1, second paragraph, Figures ES-1, 1-1, and 1-2. In the text on p. 2-1, second paragraph, there are two references to the "USGS gauging station". The station name associated with this gaging station should be identified. It may actually refer to the station "13320300 CATHERINE CREEK AT UNION, OREG," as shown in figures ES-1, 1-1, and 1-2. This gaging station does not seem to have ever been operated by the USGS. Elsewhere in the text, this stream gage is identified as "OWRD STREAM GAGE" or stream gage 13320300. The gaging station farther south near Badger Flat, which is referred in the text as " 13320000 CATHERINE CREEK NEAR UNION, OREG," was originally a USGS gaging station from 1911 to about 1996 when it seems that OWRD took over operation of the stream gage. The station name or number should be provided in the text of the subject paragraph and usage should be made consistent with the figures and elsewhere in the text. 
Section 4-p. 4-2, third paragraph. "U.S. Geological Service" to should be corrected to "U.S. Geological Survey."

Figures ES-3, 3-1, 3-2, 3-3, 3-4, and 5-1. The scale values shown on the maps in these figures do not match the size as provided in the digital document that was received for review. These figures have a page size of $8.5 \times 11$ inches; however, paper size may have been reduced during publishing. Scale bars seem to be correct and are sufficient. The stated and approximate scales as published for each figure are as follows:

- Figures ES-3 and 3-1 state a scale of 1:42,000 but, as published, have a scale of about $1: 66,700$.

- Figure 3-2 states a scale of 1:52,800 ("1 inch equals 1 mile") but, as published, has a scale of about 1:88,400 with 1 in. equal to about $1.4 \mathrm{mi}$.

- Figures 3-3 and 3-4 state a scale of 1:31,680 ("1 inch equals 0.5 mile") but, as published, have a scale of about 1:52,800 with 1 in. equal to about $0.83 \mathrm{mi}$.

- Figure 5-1 states a scale of 1:37,000 but, as published, has a scale of about 1:63,360.

Figures ES-1 and 1-1. A scale bar for these figures would be helpful. 


\section{Appendix B. Analysis of Water and Aquifer Storage Requirements}

The volume of water to be stored to attain the streamflow augmentation goals for Catherine Creek presented in table B1 can be used to determine the aquifer characteristics needed to accommodate the storage of the water. The determination of the aquifer characteristics is dependent on whether the aquifer is unconfined or confined.

Table B1. Water volume required for storage of recharge water, upper Catherine Creek watershed, Union County, northeastern Oregon.

[Recovery and recharge volumes were obtained from Table 2-1 of the "Upper Catherine Creek Storage Feasibility Study Grande Ronde Model Watershed" (Anderson Perry and Associates, Inc., 2010), with modifications as discussed in this report (sections, "Executive Summary" and "Section 2-Existing Stream Flows") Recharge storage volume: The Oregon Water Resources Department will limit the available recovery under a secondary permit to 85 percent of the recharge volume]

\begin{tabular}{|c|c|c|}
\hline \multirow{2}{*}{} & \multicolumn{2}{|c|}{ Water volume required for storage of recharge water } \\
& (acre-feet) \\
\cline { 2 - 3 } & $\begin{array}{c}\text { Flow augmentation at } \\
\text { 1 cubic foot per second }\end{array}$ & $\begin{array}{c}\text { Flow augmentation at } \\
10 \text { cubic feet per second }\end{array}$ \\
\hline $\begin{array}{c}\text { Target recovery volume, } \\
\text { in acre-feet }\end{array}$ & 244 & 2,440 \\
\hline $\begin{array}{c}\text { Recharge storage volume, } \\
\text { in acre-feet } \\
\text { (assuming 85 percent recovery) }\end{array}$ & 287 & 2,871 \\
\hline
\end{tabular}


An unconfined aquifer has a water table with saturated conditions below and unsaturated conditions above. The addition of water to an unconfined aquifer is stored in the interconnected pore spaces within the unsaturated zone, raising the water table (after the water table reaches the surface, ponding will occur). The volume of unconfined aquifer needed to accommodate a specified volume of water is determined as:

$$
V_{a q}=\frac{V_{w}}{S_{y}}
$$

where $V_{a q} \quad$ is the volume of unconfined aquifer needed to store a specified volume of water (units of length ${ }^{3}$ ),

$V_{w} \quad$ is the volume of water to be stored (units of length ${ }^{3}$ ), and

$S_{y} \quad$ is the specific yield of the unconfined aquifer (dimensionless).

Specific yield is defined as the ratio of the volume of water that the porous medium, after being saturated, will yield by gravity to the volume of the porous medium (Lohman, 1972, p. 6). The value of specific yield for unconfined aquifers of all rock types typically ranges from 0.01 to 0.30 (Freeze and Cherry, 1979, p. 61). Estimates of the unconfined aquifer volume required for storage of recharge water needed to meet goals for augmentation of streamflow for Catherine Creek across the typical range of specific yields are presented in table B2. For the CRBG, the largest value of specific yield reported from previous studies is about 0.01 (Davies-Smith and others, 1988, p. 18; Drost and others, 1997, p. 41; Kahle and others, 2011, p. 25-26). If the Grande Ronde aquifer were under unconfined conditions, relatively large volumes of aquifer would be needed to store the recharge volume of water intended for the MUS system (table B2).

Table B2 Unconfined aquifer volume required for storage of recharge water, upper Catherine Creek watershed, Union County, northeastern Oregon.

[The values in the table represent the volume of unconfined aquifer required to accommodate the recharge storage volume for the desired flow augmentation rate for Catherine Creek. The value of specific yield for unconfined aquifers typically ranges from 0.01 to 0.30 (Freeze and Cherry, 1979, p. 61)]

\begin{tabular}{|c|c|c|}
\hline \multirow{2}{*}{$\begin{array}{c}\text { Specific yield } \\
\text { (dimensionless) }\end{array}$} & $\begin{array}{c}\text { Unconfined aquifer volume required for storage of recharge water } \\
\text { (acre-feet) }\end{array}$ \\
\cline { 2 - 3 } & $\begin{array}{c}\text { Flow augmentation at } \\
\text { 1 cubic foot per second }\end{array}$ & $\begin{array}{c}\text { Flow augmentation at } \\
\text { 10 cubic feet per second }\end{array}$ \\
\hline $\mathbf{0 . 3 0}$ & 957 & 9,569 \\
\hline $\mathbf{0 . 2 0}$ & 1,435 & 14,353 \\
\hline $\mathbf{0 . 1 0}$ & 2,871 & 28,706 \\
\hline $\mathbf{0 . 0 5}$ & 5,741 & 57,412 \\
\hline $\mathbf{0 . 0 1}$ & 28,706 & 287,059 \\
\hline
\end{tabular}


The unconfined aquifer thickness needed to store the volumes of water associated the flow augmentation goals of $1 \mathrm{ft}^{3} / \mathrm{s}(287 \mathrm{acre}-\mathrm{ft})$ and $10 \mathrm{ft}^{3} / \mathrm{s}$ (2,871 acre- $\left.\mathrm{ft}\right)$, respectively, at several values of assumed aquifer surface area and a range of specific yields are shown in figures B1 and B2. For comparison, the low-lying part of the Milk Creek sub-area is less than $1 \mathrm{mi}^{2}$.

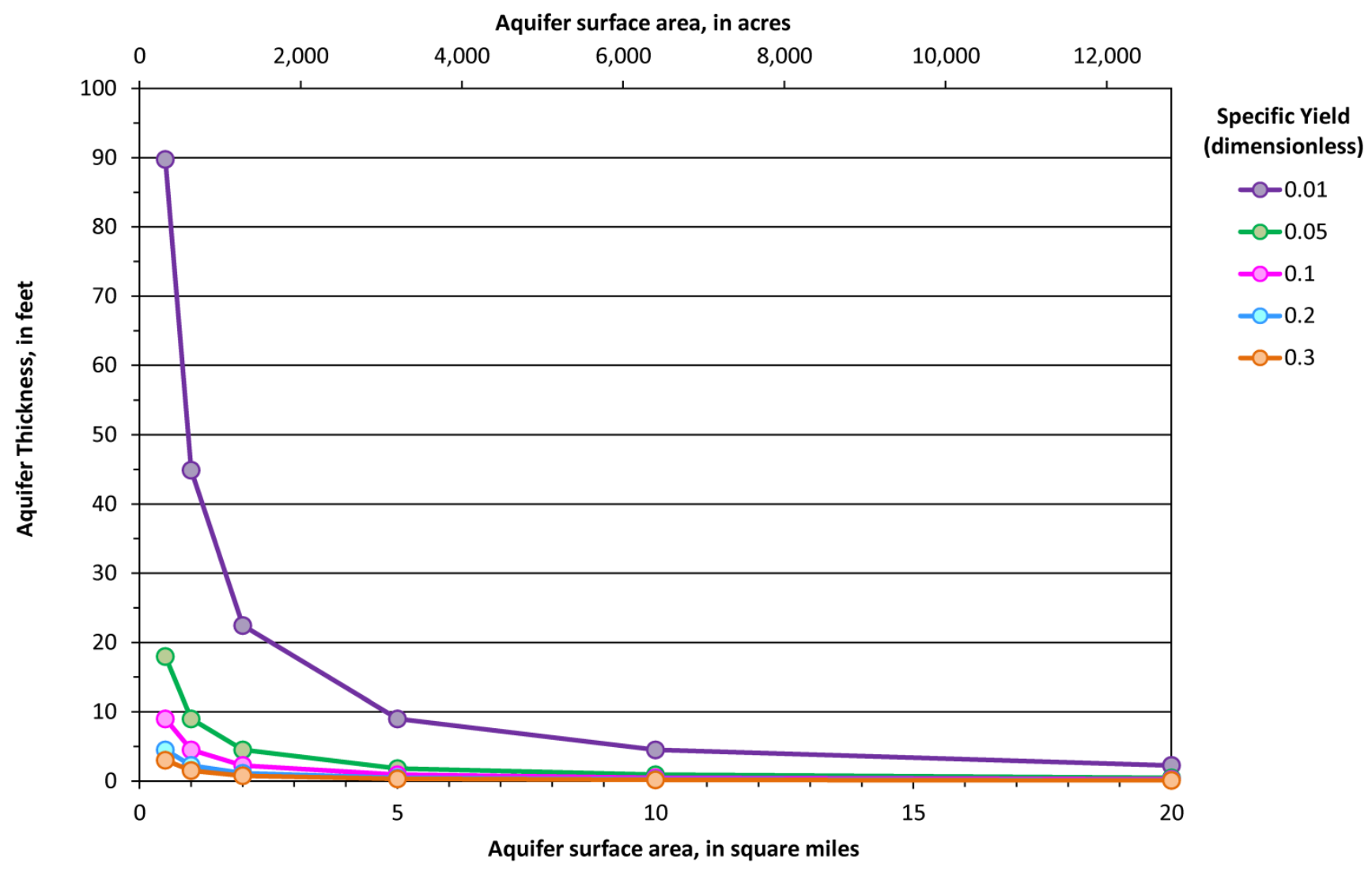

Figure B1. Graph showing relation between aquifer surface area and aquifer thickness required to store 287 acre-feet of water at various values of specific yield for an unconfined aquifer, upper Catherine Creek watershed, Union County, northeastern Oregon. This volume of water is needed to obtain the goal of augmenting the streamflow of Catherine Creek by 1 cubic foot per second. For the Columbia River Basalt Group, the largest value of specific yield reported from previous studies is about 0.01 (Davies-Smith and others, 1988, p. 18; Drost and others, 1997, p. 41; and Kahle and others, 2011, p. 25-26). 


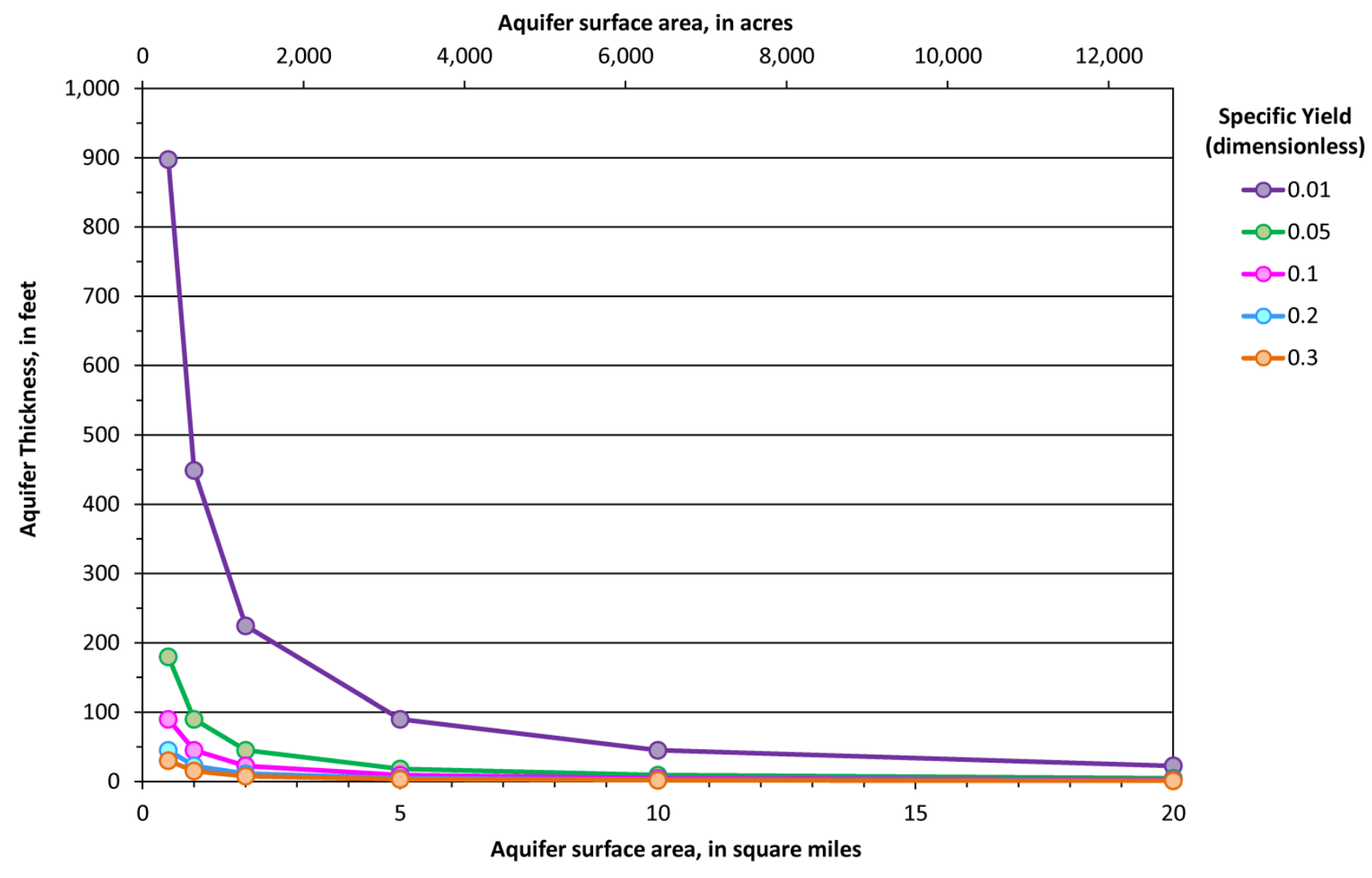

Figure B2. Graph showing relation between aquifer surface area and aquifer thickness required to store 2,871 acre-feet of water at various values of specific yield for an unconfined aquifer, upper Catherine Creek watershed, Union County, northeastern Oregon. This volume of water is needed to obtain the goal of augmenting the streamflow of Catherine Creek by 10 cubic feet per second. For the Columbia River Basalt Group, the largest value of specific yield reported from previous studies is about 0.01 (Davies-Smith and others, 1988, p. 18; Drost and others, 1997, p. 41; and Kahle and others, 2011, p. 25-26). 
The presence of flowing artesian wells in the Milk Creek sub-area indicates that the Grande Ronde aquifer is confined in this area. A confined aquifer is an aquifer that lies between two relatively impermeable rock layers, which may result in the water being under pressure. The addition of water to a confined aquifer increases the head, which increases fluid pressure causing the mineral skeleton of the aquifer to expand, increasing the porosity and available storage for water. Additionally, the increase in pressure causes the water to compress, enabling more water to be stored in the same volume. However, these effects result in much larger head changes for a given volume of stored water as compared to unconfined aquifers. The volume of water stored to or released from a confined aquifer as the head is raised or lowered, respectively, may be calculated using the formula (Fetter, 1994, p. 118):

$$
V_{w}=S A \Delta h
$$

where $V_{w} \quad$ is the volume of water stored to or drained from the aquifer (units of length ${ }^{3}$ ), $S \quad$ is the storage coefficient (dimensionless),

$A \quad$ is the surface area overlying the drained aquifer (units of length ${ }^{2}$ ), and

$\Delta h \quad$ is the average change in head (units of length).

The change in head needed to accommodate the storage of a given volume of water for a given surface area and storage coefficient is then calculated as:

$$
\Delta h=\frac{V_{w}}{S A}
$$

The storage coefficient is defined as the volume of water an aquifer releases from or receives into storage per unit surface area of the aquifer per unit change in head (Lohman, 1972, p. 8). The value of the storage coefficient in confined aquifers is about 0.005 or less (Freeze and Cherry, 1979, p. 60; Fetter, 1994, p. 118). The storage coefficient for the Grande Ronde aquifer determined from previous studies ranged from a maximum of 0.006 to a minimum of 0.0000014 , with a median of 0.00052 (Davies-Smith and others, 1988, p. 18; Hansen and others, 1994, p. 32-33; Packard and others, 1996, p. 57; Kahle and others, 2011, p. 25-26). Figures B3 and B4 show the change (rise) in head needed to store the volumes of water associated the flow augmentation goals of $1 \mathrm{ft}^{3} / \mathrm{s}(287$ acre- $\mathrm{ft})$ and $10 \mathrm{ft}^{3} / \mathrm{s}$ $(2,871$ acre-ft $)$, respectively, at several values of assumed aquifer surface area and the range of storage coefficients for the Grande Ronde aquifer. 


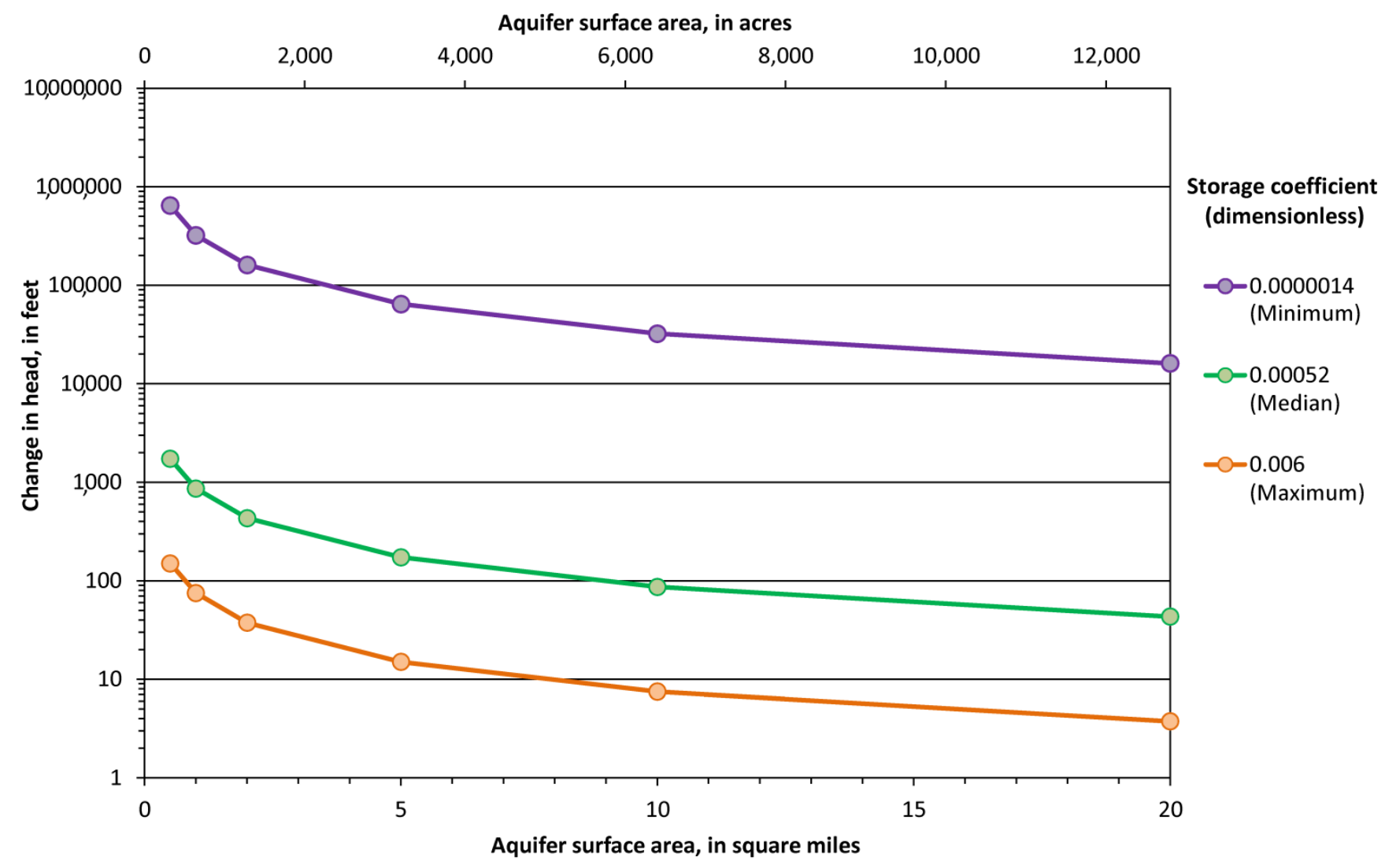

Figure B3. Graph showing relation between aquifer surface area and change in head required to store 287 acrefeet of water at various values of storage coefficient, upper Catherine Creek watershed, Union County, northeastern Oregon. This volume of water is needed to obtain the goal of augmenting the streamflow of Catherine Creek by 1 cubic foot per second. The storage coefficients of $0.0000014,0.00052$, and 0.006 are the minimum, median, and maximum values, respectively, for the Grande Ronde aquifer from previous studies (Davies-Smith and others, 1988, p. 18; Hansen and others, 1994, p. 32-33; Packard and others, 1996, p. 57; and Kahle and others, 2011, p. 25-26). 


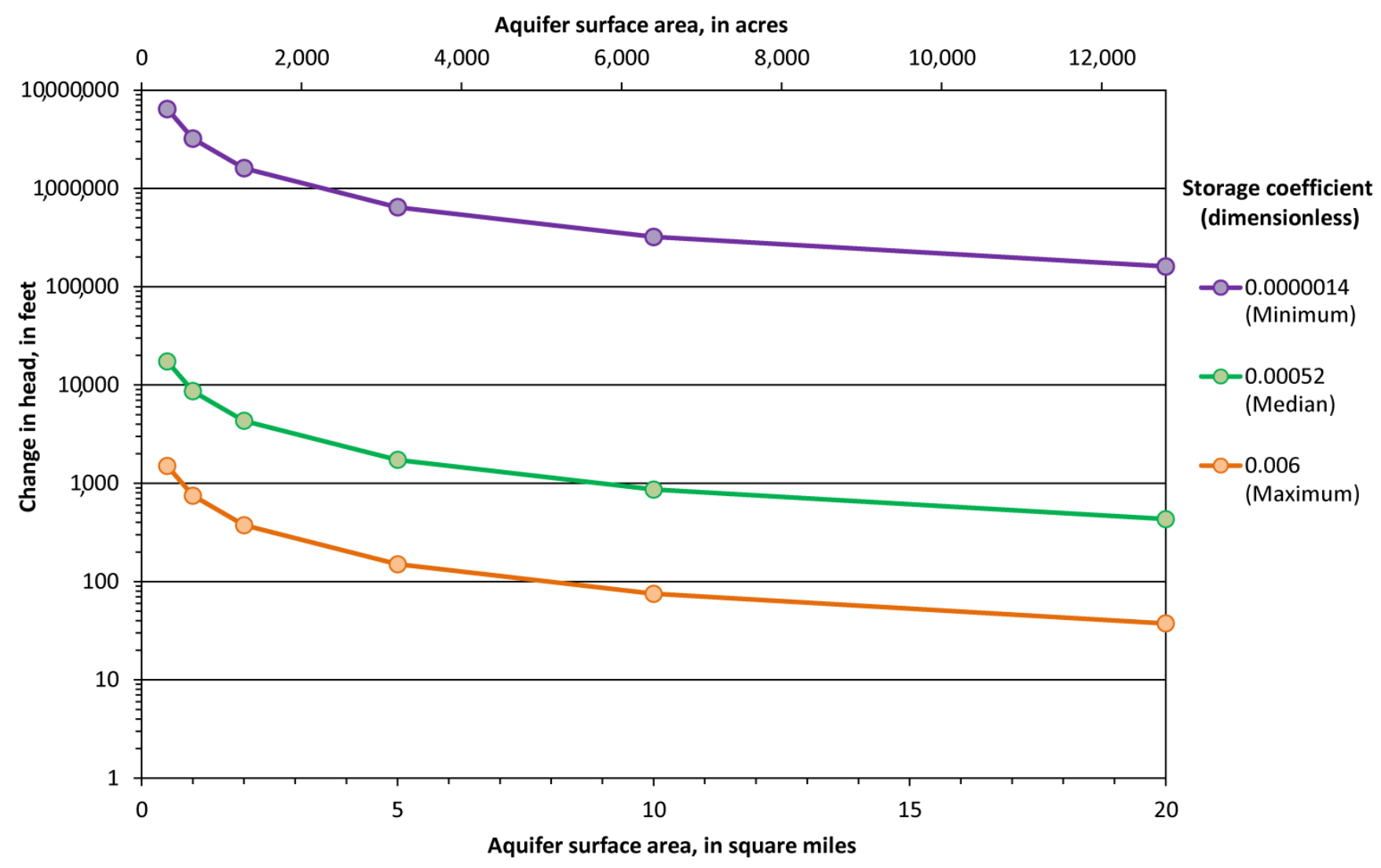

Figure B4. Graph showing relation between aquifer surface area and change in head required to store 2,871 acre-feet of water at various values of storage coefficient, upper Catherine Creek watershed, Union County, northeastern Oregon. This volume of water is needed to obtain the goal of augmenting the streamflow of Catherine Creek by 10 cubic feet per second. The storage coefficients of $0.0000014,0.00052$, and 0.006 are the minimum, median, and maximum values, respectively, for the Grande Ronde aquifer from previous studies (Davies-Smith and others, 1988, p. 18; Hansen and others, 1994, p. 32-33; Packard and others, 1996, p. 57; and Kahle and others, 2011, p. 25-26).

If the Grande Ronde aquifer were under confined conditions, it may be difficult to attain the storage goals of MUS (figs. B3 and B4). The extreme values of head (greater than hundreds of feet) that might be needed to store the recharge water volumes for the MUS system in a relatively small aquifer surface area for the range of storage coefficients observed for the Grande Ronde aquifer probably are not feasible from an engineering perspective. For comparison, the low-lying part of the Milk Creek subarea is less than $1 \mathrm{mi}^{2}$. Conversely, the large aquifer surface area (greater than tens of square miles) that might be needed to store the recharge water volumes for the MUS system with a relatively small change in head for the range of storage coefficients observed for the Grande Ronde aquifer probably are not feasible from a hydrogeologic perspective because of features that may occur at a smaller scale, such as pinchouts of the aquifer, changes in lithology, or the presence of faults (Ferns and others, 2010, p. 51; Burns and others, 2012).

Using $100 \mathrm{lb} / \mathrm{in}^{2}$ as the practical upper limit for injecting under pressure (Brett Moore, Anderson Perry and Associates, Inc., written commun., 2014) and a value of $2.31 \mathrm{ft}$ of head/lb/in ${ }^{2}$ (Lohman, 1972, p. 9) results in a practical upper limit of 231 feet of head for injecting under pressure. Using the minimum, median, and maximum values of the storage coefficient for the Grande Ronde aquifer, the 
aquifer surface area required would be 1,$400 ; 3.7$; and $0.32 \mathrm{mi}^{2}$, respectively, for a flow augmentation rate of $1 \mathrm{ft}^{3} / \mathrm{s}$ that requires a recharge water volume of 287 acre- $\mathrm{ft}$ (fig. B5). Aquifer surface areas of 14,$000 ; 37$; and $3.2 \mathrm{mi}^{2}$, respectively, would be required for a flow augmentation rate of $10 \mathrm{ft}^{3} / \mathrm{s}$ that requires a recharge water volume of 2,871 acre-ft (fig. B5).

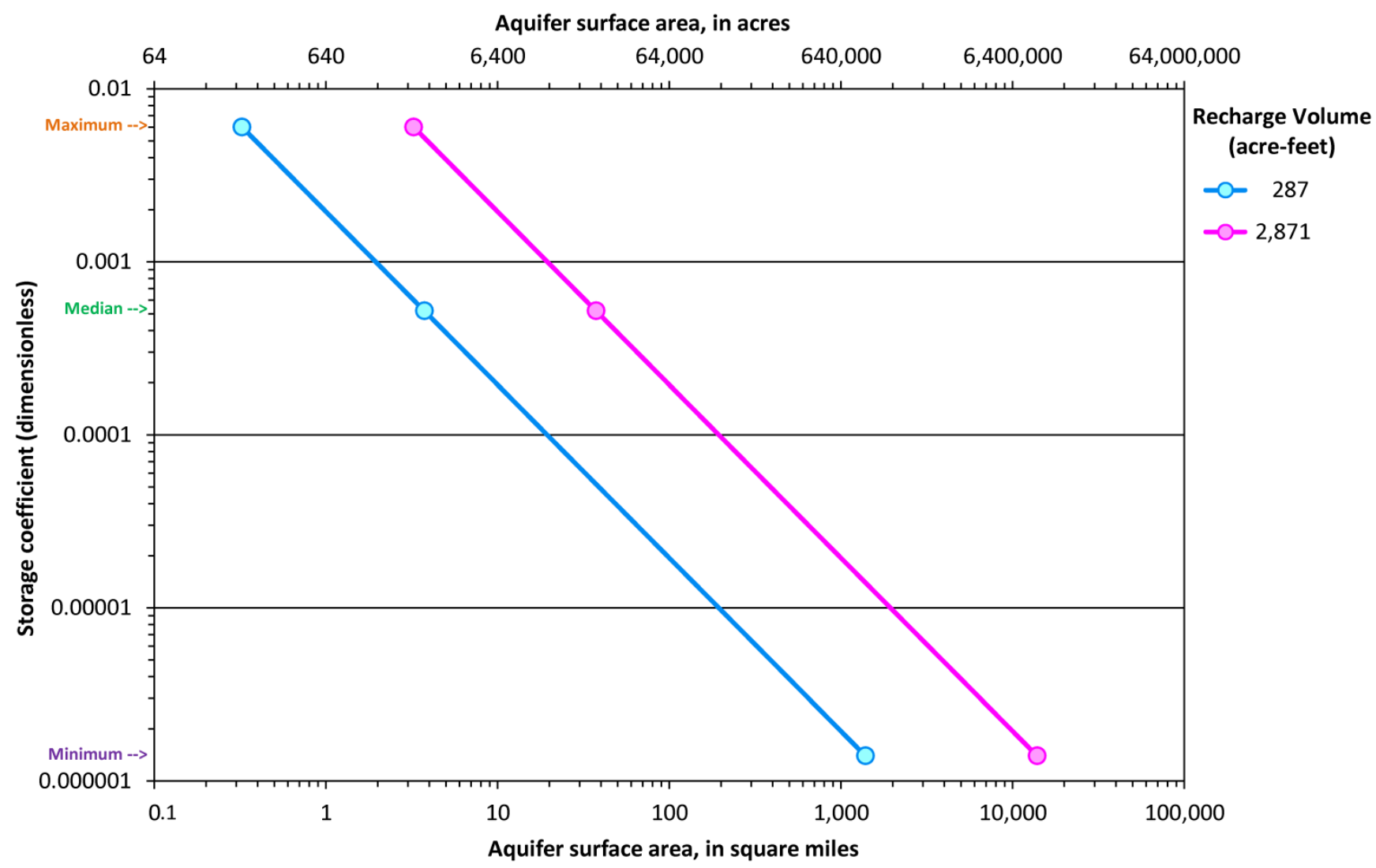

Figure B5. Graph showing relation between aquifer surface area and storage coefficient required to store 287 or 2,871 acre-feet of water at a maximum head of 231 feet, upper Catherine Creek watershed, Union County, northeastern Oregon. These volumes of water are needed to obtain the goal of augmenting the streamflow of Catherine Creek by either 1 or 10 cubic feet per second, respectively. A maximum head value of 231 feet was determined to be the practical upper limit for injecting water into an aquifer under pressure. The storage coefficients of $0.0000014,0.00052$, and 0.006 , are the minimum, median, and maximum values, respectively, for the Grande Ronde aquifer from previous studies (Davies-Smith and others, 1988, p. 18; Hansen and others, 1994, p. 32-33; Packard and others, 1996, p. 57; and Kahle and others, 2011, p. 25-26).

In summary, the storage of water in an unconfined aquifer represents an actual storage of water in the soil pores, whereas storage in a confined aquifer represents only the secondary effects of water expansion and aquifer compaction caused by changes in fluid pressure. As a result, large head changes across extensive areas are required to store or to yield substantial quantities of water from confined aquifers as compared to unconfined aquifers (Freeze and Cherry, 1979, p. 60-62). 
Publishing support provided by the U.S. Geological Survey Publishing Network, Tacoma Publishing Service Center

For more information concerning the research in this report, contact the Director, Oregon Water Science Center

U.S. Geological Survey

2130 SW 5th Avenue

Portland, Oregon 97201

http://or.water.usgs.gov 
